IZA DP No. 8722

Bentham or Aristotle in the Development Process? An Empirical Investigation of Capabilities and Subjective Well-being

Carol Graham

Milena Nikolova

December 2014 


\title{
Bentham or Aristotle in the Development Process? An Empirical Investigation of Capabilities and Subjective Well-being
}

\author{
Carol Graham \\ Brookings Institution, \\ University of Maryland and IZA \\ Milena Nikolova \\ IZA and Brookings Institution
}

Discussion Paper No. 8722

December 2014

\author{
IZA \\ P.O. Box 7240 \\ 53072 Bonn \\ Germany \\ Phone: +49-228-3894-0 \\ Fax: +49-228-3894-180 \\ E-mail: iza@iza.org
}

Any opinions expressed here are those of the author(s) and not those of IZA. Research published in this series may include views on policy, but the institute itself takes no institutional policy positions. The IZA research network is committed to the IZA Guiding Principles of Research Integrity.

The Institute for the Study of Labor (IZA) in Bonn is a local and virtual international research center and a place of communication between science, politics and business. IZA is an independent nonprofit organization supported by Deutsche Post Foundation. The center is associated with the University of Bonn and offers a stimulating research environment through its international network, workshops and conferences, data service, project support, research visits and doctoral program. IZA engages in (i) original and internationally competitive research in all fields of labor economics, (ii) development of policy concepts, and (iii) dissemination of research results and concepts to the interested public.

IZA Discussion Papers often represent preliminary work and are circulated to encourage discussion. Citation of such a paper should account for its provisional character. A revised version may be available directly from the author. 
IZA Discussion Paper No. 8722

December 2014

\section{ABSTRACT}

\section{Bentham or Aristotle in the Development Process? An Empirical Investigation of Capabilities and Subjective Well-being ${ }^{1}$}

Life evaluations and emotional states are distinct subjective well-being (SWB) components. We explore the relationship between opportunities and SWB dimensions, distinguishing between actual capabilities and means (education, employment, and income) and perceived opportunities (autonomy and health perceptions and belief in hard work). We find a link between capabilities and SWB (particularly, life evaluations), which varies across world regions. Capabilities can also be associated with stress and anger and seem to matter the least for the happiest respondents. We also explore the determinants of the least studied well-being dimension: eudaimonia, or life purpose, which is an underlying objective of the development process.

JEL Classification: $\quad$ I31, I39

Keywords: $\quad$ well-being, capabilities, freedoms, variance decompositions

Corresponding author:

Milena Nikolova

IZA

P.O. Box 7240

53072 Bonn

Germany

E-mail: nikolova@iza.org

\footnotetext{
${ }^{1}$ Graham serves as an academic advisor to the Gallup polls and, as such, has access to the data. The authors would like to thank Peter Murrell, Madiha Afzal, David Crocker, Clifford Gaddy, Matt Adler, Ed Diener, Jan-Emmanuel De Neve, Richard Florida, Eduardo Lora, and participants at a Duke University workshop on well-being for encouraging comments and helpful suggestions. Derek Stemple provided excellent proofreading and editing help. All remaining errors are ours.
} 


\section{Introduction and Theory \\ 1.1. Human Well-being and Capabilities}

Human well-being is a multidimensional concept, and defining and measuring the distinct wellbeing elements can broaden and deepen our understanding of social welfare. Subjective well-being (SWB) metrics complement income-based indicators, such as Gross Domestic Product (GDP), to furnish a more comprehensive view of the human condition. Moreover, a fundamental well-being component, which is the focus of this study, is the individual capacity to make autonomous choices and pursue a fulfilling life. The purpose of this paper is to contribute to our understanding of actual and perceived aspects of this capacity and their empirical relationship with SWB dimensions (i.e., hedonic, evaluative, and eudaimonic, which are defined below). We implicitly argue that human development and well-being are ultimately about enlarging individual choices and opportunities so that people can pursue the kinds of lives they choose and value (Sen, 1999). ${ }^{1}$

Adapting concepts from the human development approach, we define "agency" as the capacity to pursue a purposeful and fulfilling life (Graham, 2011) and "capability" as "the freedom to achieve various lifestyles" (Sen, 1999). ${ }^{2}$ Furthermore, the human development approach distinguishes between functionings - which are acts and expressions of being and doing - such as being fed, being hungry, being sheltered - and capabilities - which comprise the freedoms and opportunities to act to achieve desirable functionings (Hall, 2013). Agency is the capacity to choose among different opportunities to achieve valuable states of being and doing.

Recognizing that there are alternative perspectives and approaches, in this paper, we conceptualize of capabilities as manifestations of the capacity to live a purposeful life and are interested in how different capabilities relate to SWB dimensions. As in other quantitative studies on capabilities and SWB, in our analysis, capabilities are social indicators related to people's quality of life (Robeyns, 2005). Assuming that SWB is a function of capabilities, the goal is to identify and measure a set of such

capabilities. ${ }^{3}$ Currently, no procedural method exists for selecting capability metrics (Robeyns, 2005), and scholars use different approximations. There are several attempts to measure capability indicators based 
on questions in existing surveys (Anand et al., 2005; Ramos \& Silber, 2005; Veenhoven, 2010) and specially designed questionnaires (Anand \& van Hees, 2006; Anand et al., 2009; Anand et al., 2011; Simon et al., 2013). Anand and van Hees (2006) argue that survey questions about the "scope to achieve things" and "limitation of opportunities" can capture capabilities (p. 279).

Building on these studies, we use self-reported measures available in the Gallup World Poll (GWP) as proxies for capabilities and means. Our goal is to select variables that capture whether respondents have the opportunities, tools, and means to live the kinds of lives they have reasons to value. In the absence of a set list of capabilities and consensus on how to measure them, the selection of capability proxies based on existing data is subject to epistemological errors. Because these debates are still ongoing, we include variables that have been used in previous studies and attempt to capture a range of capability concepts. We further distinguish between objective and perceived opportunities and means to achieve things in life. The perceptions variables include: (i) perceptions of health; (ii) belief in hard work as a means of getting ahead; and (iii) satisfaction with freedom to choose in life. The objective metrics are: (i) household income (a proxy for means); (ii) education; and (iii) employment status. Ideally, we would like to measure all capability variables using objective indicators (as opposed to self-reported subjective metrics) but are constrained by the question availability in GWP (Table A.1).

\subsection{Subjective Well-being Metrics}

As noted above, SWB has three dimensions: hedonic, evaluative, and eudaimonic (Figure 1) (Durand \& Smith, 2013; OECD, 2013; Stone \& Mackie, 2014). First, evaluative well-being is a reflective assessment of one's life as a whole rather than a description of an emotional state. Judgments about life satisfaction could also be applied to specific life domains such as work, health, community, and relationships (Stone \& Mackie, 2014). This SWB dimension is measured through survey questions about satisfaction with life as a whole and the Cantril ladder of life question (which asks respondents to rank their current life relative to their best possible life) (Cantril, 1965), among others.

[Figure 1 here] 
Second, the hedonic subjective well-being dimension, or affect, reflects affective states and emotional experiences related to people's job quality, their immediate health conditions, daily work commutes, and social networks at a particular point in time. ${ }^{4}$ Hedonic well-being (which some scholars call "Benthamite") is about how people experience their lives rather than how they assess them more generally (Kahneman \& Krueger, 2006). This dimension encompasses negative emotions, such as worry and stress (i.e., negative affect), and positive emotions of pleasure, enjoyment, and happiness at the moment (i.e., positive affect). It is measured through survey questions about experiencing positive and negative feelings (e.g., "Were you happy yesterday?" and/or "Did you experience stress yesterday?"). It is important to distinguish between positive and negative affect (Figure 1) as one is not the inverse of the other, and they track differently from evaluative well-being and from one another (Stone \& Mackie, $2014)^{5}$

Research shows that respondents clearly distinguish between affect and life evaluations and answer these questions differently. For example, a very destitute person might report to be happy in the hedonic sense while also indicating low life satisfaction (Helliwell et al., 2013). From a public policy perspective, this distinction matters and can allow policymakers to better target poverty and destitution. ${ }^{6}$ In this paper, we propose that and test whether evaluative well-being is better related than hedonic wellbeing to the opportunities that people have to exercise choice and to pursue fulfilling lives (i.e., their capabilities and autonomy).

Eudaimonic well-being captures people's perceptions of meaning and purpose in their lives and reflects the Aristotelian notion of happiness as life purpose, challenges, and growth (Stone \& Mackie, 2014). This concept goes beyond reflections of life as a whole and experienced emotions and focuses on flourishing and the realization of human potential (OECD, 2013). While this is the least well-researched SWB dimension, it is arguably the most important from a development perspective. Eudaimonic wellbeing is about living well in terms of realizing one's human potential (Deci \& Ryan, 2008), which implies having the means and freedoms to fulfill one's true life purpose. While it is intuitively best captured in evaluative assessments, it may also be reflected in hedonic constructs, as there are discrepancies between 
what people find pleasurable and enjoyable - such as watching television - as opposed to what they find rewarding or meaningful - such as reading the same story repeatedly to a child (White \& Dolan, 2009; Adler et al., 2014). While there is a general consensus about the measurement, validity, and reliability of evaluative and hedonic well-being, the conceptual framework for eudaimonic well-being is less wellestablished (OECD, 2013).

Evaluative and hedonic SWB metrics are valid and reliable, psychometrically sound, internally consistent and comparable across individuals, different levels of development, and over time (Diener et al., 1999; Diener et al., 2013; Helliwell et al., 2010; Krueger \& Schkade, 2008). Furthermore, they are increasingly used in public policy and economic analyses and have become a part of official statistical gathering efforts in countries such as the United Kingdom (Diener et al., 2009; Di Tella \& MacCulloch, 2006; O'Donnell, 2013; Stone \& Mackie, 2014). ${ }^{7}$ The growing SWB literature indicates that SWB determinants are consistent across different societies and levels of development. In particular, unemployment, divorce, and economic volatility are negatively associated with SWB, while health and stable partnerships have a positive association with it (Graham, 2011; Kahneman \& Krueger, 2006). Furthermore, women have a higher average life satisfaction than men (OECD, 2011), except in lowincome countries (Graham and Chattopadhyay, 2013). Age has a U-shaped relationship with SWB, with the turning point occurring around age 40 (Frey \& Stutzer, 2002), and both absolute and relative income matter for SWB (Clark et al., 2008; Easterlin, 1995; Senik, 2009). There are two main challenges related to the use of subjective well-being scores (OECD, 2011). First, people may adapt to bad circumstances and learn to be happy or take pleasure in immoral behavior. As a result, SWB metrics should complement rather than substitute objective metrics. Second, SWB indicators may be non-comparable across individuals and may be affected by transient external factors (OECD, 2011). The literature shows, however, that the latter concern is largely unjustified and that SWB metrics are comparable across individuals, countries, and time and predict behavior reasonably well (OECD, 2011).

The literature shows that evaluative and hedonic well-being have different correlates. Kahneman and Deaton (2010) find that health, caregiving, loneliness, and smoking better predict hedonic well-being, 
while income and education (which are objective capabilities and means) have a greater association with evaluative well-being. The positive correlation between hedonic well-being and income ends at about $\$ 75,000$, but the association between income and evaluative well-being (i.e., best possible life) continues linearly. This suggests that beyond a certain threshold, additional income cannot enhance daily emotions (although insufficient income is clearly linked to suffering and negative moods), but higher levels of income offer more choices and opportunities. Similarly, Tay and Diener (2011) find that life evaluation is more closely associated with basic needs fulfillment and country-level economic conditions, while positive and negative affect are more closely linked with individual-level conditions (social ties, respect, and autonomy).

Graham and Lora (2009) show that the most pertinent variables for the reported life satisfaction of the Latin American poor (i.e., those with incomes below the median), after having enough food to eat, are friends and family on whom to rely in times of need. In contrast, the most important factors for the life satisfaction of the rich (i.e., those with incomes above the median) are work and health. Friends and family are likely the vital safety nets that make daily life tolerable for the poor in the hedonic sense, while work and health provide respondents means to make life choices.

Another manifestation of the different SWB dimensions that individuals emphasize is the "happy peasant and frustrated achiever" paradox, whereby very poor people state that they are happy at the same time that cohorts experiencing positive income change and mobility report deep frustration (Graham and Pettinato, 2002). It is likely that low-income respondents, who have adapted to adversity, emphasize positive hedonic well-being (e.g., happiness), while those with raised expectations in the process of acquiring means and capabilities are thinking about their lives as a whole (i.e., evaluative well-being). In addition, the process of acquiring capabilities is unpleasant (especially in terms of hedonic well-being) as it is paved with uncertainty, rapid change, and altered norms and reference groups (Graham \& Lora, 2009).

The latter statement hinges on the unanswered question of whether some unhappiness necessarily underlies the search for opportunity and progress or whether the associated changes reduce subjective 
well-being (in all its dimensions), at least in the short-term. Individuals who focus primarily on daily (i.e., hedonic) experiences - due to low expectations, lack of autonomy, or imposed social norms - may have less incentive to invest in the future. In contrast, those who are forward-looking and goal-oriented may at times sacrifice daily experiences for longer-term objectives and anticipated well-being in the future. Unfortunately, because our dataset is a pooled cross-section rather than a panel, we cannot explore dynamics over time and the possibility of sacrificing hedonic well-being for long-term gains, nor can we address issues of causality.

\subsection{Research Questions and Contributions}

Empirical research has established the correlation between capabilities and SWB (Anand \& van Hees, 2006; Anand et al., 2005, 2009; Van Ootegem \& Spillemaeckers, 2010; Veenhoven, 2010) and the link between freedom of choice/locus of control and well-being (Becker et al., 2012; Veenhoven, 2000; Verme, 2009). ${ }^{8}$ In this paper, we build on research suggesting that which subjective well-being dimension individuals emphasize may be mediated by their capacity to control their lives (Graham \& Lora, 2009; Graham \& Pettinato, 2002; Kahneman \& Deaton, 2010). We test the relationship between subjective wellbeing and objective and perceived freedoms and opportunities in three world regions representing different levels of development - the EU-15, Latin America and the Caribbean (LAC), and transition economies. Our main goal is to discern the relative importance of objective vs. perceived opportunities for different subjective well-being dimensions.

Our study asks the following questions: (i) Are perceived or actual opportunities and means more important for evaluative or hedonic well-being? (ii) Does the well-being-opportunities link differ across world regions at different levels of development? (iii) Does a given set of tools and capabilities have the same association with evaluative well-being for the happiest and unhappiest respondents?

We find that the same set of capabilities and means is more important for life evaluations (i.e., evaluative well-being) than for experienced happiness (i.e., hedonic well-being). Second, the regional comparisons indicate a pattern across development levels, with respondents in the wealthier EU-15 countries putting a smaller emphasis on income but a higher emphasis on freedom than respondents in 
transition economies and Latin America and the Caribbean (LAC), which corroborates previous research findings (Inglehart et al., 2008). Smiling and personal characteristics are particularly important for the emotional states (i.e., experienced happiness) of respondents in poorer regions. ${ }^{9}$

Third, we find that citizens in the former socialist countries in Central and Eastern Europe and Central Asia value belief in hard work when they think about their lives as a whole, as much as those in the rich EU-15 countries, and value freedom more than their counterparts in the less-developed LAC context. Fourth, we provide novel evidence about eudaimonic well-being (meaning and purpose in life). We find that perceived capabilities, personal and family traits, hedonic affect, and between-country differences are the biggest predictors of meaning and purpose in life worldwide. Fifth, we show that most perceived and actual capabilities and means are less important to SWB at the highest levels of the SWB distribution. Finally, our findings suggest that while employment can promote hedonic and evaluative well-being, it can also contribute to stress and anger.

\section{Methods}

\subsection{Main Model}

We explored the subjective well-being dimension $Y$ of individual $i$, in year $t$, residing in country $c$, conditioned on the standard socioeconomic and demographic traits:

$Y_{i t c}=X^{\prime}{ }_{\text {itc }} \alpha+T^{\prime}{ }_{\text {itc }} \beta+Z^{\prime}{ }_{\text {itc }} \gamma+\kappa_{\mathrm{c}}+\tau_{\mathrm{t}}+\varepsilon_{\mathrm{itc}}$

where $X$ is a vector of self-reported objective and perceived capabilities and means (the absence of a health problem, belief in hard work, perceptions of autonomy, and income, education, and employment); $T$ is a vector of observed individual-level variables such as gender, age, marital status, and others; $Z$ is a vector of person-specific observed household-level variables such as household size, household location (i.e., rural or urban), and others; $\alpha, \beta$, and $\gamma$ are coefficient vectors; $\kappa_{c}$ represents country dummies; $\tau_{t}$ represents controls for time (year of survey); and $\varepsilon_{i t c}$ is the stochastic error term. For ease of interpretation,

all baseline regression equations are estimated using Ordinary Least Squares (OLS) as ignoring the ordinality of subjective well-being data has little effect on the results (Ferrer-i-Carbonell \& Frijters, 2004). 


\subsection{Variance Decompositions and Standardized Coefficient Estimates ${ }^{10}$}

To discern whether perceived or actual opportunities and means are relatively more important for evaluative or hedonic well-being, we rely on variance decompositions methods and standardized coefficient estimates. Standardized coefficient estimates measure the relative influence in the statistical sense while variance decompositions allow us to discern the relative importance of a variable based on its share of the variance (Menard, 2004). It is well-known that OLS results demonstrate the effect of a oneunit change in the independent variable on the dependent variable, holding constant the other included variables in the model, and the $R^{2}$ measures how much of the variance in the dependent variable is explained by the included independent variables. When the independent variables are not measured on the same scale, however, standardized coefficient estimates provide a measure of their relative influence (Fields, 2004).

In addition to the standardized coefficient estimates, we provide variance decomposition results. In a method proposed by Fields (2003), the variation in the dependent variable is decomposed so that the total variance is equal to the sum of the variances explained by each variable. If the standard regression equation is: ${ }^{11}$

$$
Y=\beta^{0}+\sum_{k=1}^{K} X^{k} \beta^{k}+\varepsilon, \mathrm{K}=1, \ldots \mathrm{n},
$$

the variance of $\mathrm{Y}$ can be decomposed as:

$$
\operatorname{var}(Y)=\sum_{k=1}^{K} \operatorname{cov}\left[X^{k} \beta^{k}, Y\right]+\operatorname{cov}[\hat{\varepsilon}, Y]
$$

The share of the variance of $Y$ attributable to the $k$-th explanatory variable is given by: and the share of the residual is:

$$
s\left(X^{k}\right)=\frac{\operatorname{cov}\left[X^{k} \beta^{k}, Y\right]}{\operatorname{var}(Y)} .
$$

Expressing $s\left(X^{k}\right)$ in terms of percentage contribution to $R^{2}$ (whereby each share sums to 100 percent) results in: 


$$
p\left(X^{k}\right)=\frac{s\left(X^{k}\right)}{\operatorname{var}(Y)}
$$

Negative values for $p\left(X^{k}\right)$ are possible when the multiple regression coefficient on $\left(X^{k}\right)$ and the simple correlation coefficient on $\left(X^{k}\right)$ have the opposite signs.

\subsection{Quantile Regressions}

For the quantile regressions, we follow a method described by Binder and Coad (2011) based on Koenker and Bassett (1978). While standard regressions describe the conditional mean, quantile regressions allow us to explore the entire conditional distribution by analyzing the effects of the covariates at different points of the well-being distribution. Rather than splitting the sample into segments based on values of the dependent variable (and thus losing statistical validity), quantile regressions weigh data points depending on whether they are above or below the best fit line. In essence, quantile regressions work like OLS, but instead of minimizing the sum of squared residuals, they minimize the sum of equally weighted absolute residuals (for the median) and the sum of differentially weighted residuals for the other quantiles (Neumayer et al., 2014). For example, if regressions are estimated at the 75 th percentile, then observations above the best fit line are given weights that are 7.5 times higher than those below the best fit line (Binder \& Coad, 2011).

Quantile regressions have several informational and methodological advantages. First, from a policy perspective, it may be important to understand the distribution's extremes in order to know whether particular policies (e.g., enhancing capabilities through universal education) are equally relevant for the happiest and unhappiest individuals. Second, from a normative point of view, some policies may have a small positive effect on the majority but still be morally problematic if they create disproportionate gains or losses for a minority. Quantile regressions allow us to explore such dynamics. Third, methodologically, estimating means across heterogeneous populations may seriously under- or over-estimate the impacts or even fail to identify some effects. Quantile regressions do not assume that the error terms are identically distributed at all points of the conditional distribution, which allows for individual heterogeneity as the slope parameters differ along the quantiles (Binder \& Coad, 2011). 
The quantile equations are operationalized using Stata's -sqreg- command (with bootstrapped standard errors with 20 replications). ${ }^{12}$ Binder and Coad's work $(2011 ; 2014)$ highlights the differential importance of education, social factors, income, and unemployment diminishes at higher levels of the happiness distribution. For instance, while education is positive for SWB in general, it is negatively correlated with SWB at the top of the happiness distribution. This could be due to the fact that learning makes the "happy peasants" realize their absolute or relative deprivation and lack of choice and opportunities. It may also be that the most educated have unrealistic expectations and ambitions and even their autonomy and capabilities cannot make them happy (Graham, 2011). It is likely, therefore, that the same capabilities and means have different meaning and importance for people at different points of the SWB distribution.

\section{Data}

The data are from the Gallup World Poll (GWP), which is an annual survey run by the Gallup Organization in roughly 160 countries worldwide since 2005 , with one wave per year. The survey has nationally representative coverage in most countries - Gallup weighs the data in each country to address this issue - and the sample size ranges from more than 4,000 household interviews in China every year to 500 households in Puerto Rico. ${ }^{13}$ While it is remarkable that the poll covers most countries around the world, a drawback is that there are proportionately more responses for small countries than for large ones. Gallup oversampled some of the European countries and China in 2010-2012, among others, in an effort to increase the sample size for the larger countries, which mitigated but did not eliminate the problem.

Because different individuals are interviewed each year, we have pooled cross-sections including year dummies - rather than a panel. As such, we cannot address issues of causality, but we do use several measures of capabilities and means to establish correlations (or lack thereof) with each wellbeing dimension. The surveys are completed face-to-face in countries where telephone coverage is limited and by telephone in those where it is universal (primarily the OECD countries). The difference in interview mode may introduce some biases in subjective well-being responses, and we try to control for these to the extent we can. ${ }^{14}$ In addition to the wide range of questions in GWP that assess socio- 
demographics, macroeconomic and social conditions, and political freedom, among others, we utilize several questions which capture the three well-being dimensions (i.e., hedonic, evaluative, and eudaimonic). Table A.4 shows the countries included in this paper.

\subsection{Dependent Variables}

We use five dependent variables (in separate regressions) (Figure 1 and Table A.1). First, we measure evaluative well-being using the best possible life (BPL) Cantril ladder question, which asks respondents to compare their life to the best possible life they can imagine on an eleven-point scale, corresponding to the steps on the notional ladder, where zero represents the worst possible life, and ten corresponds to the best possible life (Figure 2). Because it frames the reported SWB to a notional reference norm (i.e., one's best possible life), answers to this question typically correlate more closely with income than open-ended happiness or life satisfaction questions (Graham et al., 2010)..

Second, we use one variable to assess positive hedonic well-being, namely, whether the respondent experienced happiness yesterday, and two variables for negative hedonic well-being, i.e., whether the respondent felt stress and whether he or she experienced anger yesterday. The hedonic wellbeing metrics are binary (i.e., with possible values being no or yes). Third, we also present novel evidence about the relationship between various capabilities and means and a proxy variable for eudaimonic wellbeing, the well-being dimension related to meaning and purpose in life. The question was asked in 20092011 in several countries. ${ }^{15}$

[Figure 2 here]

\subsection{Focal Independent Variables}

We included household income, employment status, and educational attainment as proxies for objective capabilities and means. GWP's employment categories distinguish between those employed fulltime, the self-employed, part-time employees (both voluntarily and involuntarily), the unemployed, and those out of the labor force. In all regressions, the reference group is "out of the labor force." In addition, 
we captured self-reported perceptions of capabilities and means, including perceptions of health, satisfaction with freedom to choose, and belief that hard work gets you ahead in life (Table A.1). ${ }^{16}$

First, the health perception variable is based on a question asking respondents whether they have health problems preventing them from doing things that other people their age normally do. We define this variable as the absence of a health problem or the capability to engage in activities. The literature shows a strong positive association between health and SWB, which is stronger than that between well-being and income, with the causality running both ways (Graham, 2008; Veenhoven, 2010). Health is important for allowing individuals to take advantage of other opportunities and is one of Nussbaum's ten central capabilities (2011). ${ }^{17}$ Second, belief in hard work as a means of getting ahead reflects perceptions of social mobility and fairness. For example, Americans have a lower inequality aversion than Europeans (Alesina et al., 2004), likely partly because of the belief that inequality signifies that one can get ahead through hard work. This variable therefore reflects people's perceptions of the importance of individual effort vs. the role of luck or political connections. Third, the satisfaction with freedom variable relates to respondents' opportunities to choose what to do with their lives and is a proxy for autonomy (i.e., agency). Research shows that those who believe that outcomes in their lives depend on internal factors, such as effort, appreciate freedom more than those who believe in factors beyond their control, such as destiny (Verme, 2009).

\subsection{Other Controls}

In addition to the socio-demographic variables (age, age squared, gender, marital status, religiosity, household size, presence of children in the household, urban/rural location), we included two additional controls for whether the respondent: (i) smiled yesterday and (ii) learned or did something interesting the day before. First, those with higher levels of positive affect (i.e., smiling) may be more likely to perceive that they have capabilities and means. Because both happiness and capabilities are selfreported, unobservable personality traits likely play a big role, implying that the capabilities-well-being relationship suffers from endogeneity. ${ }^{18}$ 
There are some drawbacks to including the smiling yesterday variable as a control, as it is clearly correlated with happiness yesterday. Yet much of SWB is determined by innate character traits, and best practice is to control for these to the extent possible, even in a cross-section. Smiling yesterday is the available variable that most closely captures innate positive affect. Including this variable does not lead to a dominant variable effect as the rest of the regressors are statistically significant, suggesting that smiling yesterday serves as the intended control. As a robustness check, we ran the same regressions without smiling yesterday and with an alternative control for optimism - a question which asks respondents if they agree with the statement, "Even when things go wrong, you feel very optimistic." The results available in Tables A.2-A.3 are modestly different from the main results, but the substantive findings and conclusions still hold. Because the optimism question was only asked in select years and thus would limit our sample size, we have kept smiling as the control variable in the main regressions.

In addition, learning is likely positively correlated with SWB, especially for respondents who have means and opportunities, and is thus an important mediating variable. It may moreover decrease evaluative or hedonic well-being or add to the stress and anger of those lacking capabilities. For example, research shows that learning through information and communication technologies is positively linked to SWB, but it leads to frustration among poor cohorts, likely because of providing information about material goods or opportunities and choices they lack (Graham and Nikolova, 2013).

\section{Results}

\subsection{Summary Statistics}

Table 1 provides the summary statistics for all variables used in the analyses for the world sample as well as for transition economies, the EU-15 countries, and Latin America and the Caribbean (LAC). ${ }^{19}$ Citizens in transition countries have lower evaluative and positive hedonic well-being and experience more anger than those in the EU-15 and LAC, but they report lower stress levels. Transitional citizens are also less likely to report that they are healthy, believe in hard work, and are less likely to be satisfied with their freedom than respondents in other regions. The result that the residents of ex-socialist countries report lower satisfaction with freedom than Latin Americans resonates with Inglehart et al.'s (2008) 
finding that 21 percent of transitional citizens responded that they had a great deal of choice, compared with 45 percent of Latin Americans. In terms of objective capabilities and means, transitional citizens are slightly less educated than respondents in the EU-15 but are more educated than those in LAC. There is a big household income disparity between the EU-15 countries and the other two world regions: the purchasing-power-parity-adjusted household incomes in the EU-15 are more than three times higher than those in transition economies and more than four times higher than those in LAC.

[Table 1 here]

\subsection{Main Results: Best Possible Life and Hedonic Happiness}

Table 2 demonstrates the main findings regarding the association of the different objective and perceived capabilities with evaluative well-being $(B P L)$ and positive affect (experienced happiness yesterday) in the worldwide sample. The table shows the unstandardized OLS coefficient estimates, the fully standardized coefficients, and the percentage contribution of each included variable to the total explained variance. This discussion will focus on the decomposition results. The interpretation of the standardized coefficients is in terms of standard deviations. For example, based on Table 2, one standard deviation increase in log income is associated with a 0.202 standard deviations increase in the predicted BPL.

The $R^{2}$ value indicates that the included variables explain about 30 percent of predicted BPL and about a quarter of the variation in predicted hedonic happiness. ${ }^{20}$ Socio-demographic variables (age, age squared, gender, marital status, religiosity, household size, child in the household, and urban/rural location) constitute only about two percent of the explained variation in both hedonic and evaluative wellbeing. Country and year of survey explain almost half of the variation in BPL and a fifth of the variation in happiness. Table 2 demonstrates that both objective and subjective capabilities are more important for BPL than for hedonic happiness, while as expected, positive affect (i.e., smiling yesterday) is more relevant for hedonic happiness. Capabilities (both objective and perceived) explain about 40 percent of the 
variation in BPL but only 12 percent of the variation in happiness (while smiling yesterday explains 55 percent of the latter variation). When smiling is excluded from the analyses, capabilities account for 43 percent of the BPL variance and 26 percent of the happiness variance (Table A.2). When optimism is included instead of smiling (Table A.3), capabilities comprise 44 percent of the predicted BPL and 23 percent of the predicted happiness yesterday in the world sample.

Table 2 further demonstrates that objective capabilities (education, income, and employment) contribute to about a third of the variation in BPL, with income's share being 27 percent. While objective and subjective capabilities contribute to about 12 percent of the variation in happiness yesterday, perceived capabilities (health and freedom perceptions and belief in hard work) contribute to 9 percent of that variation. While in the BPL regression, household income is about three times more important than all perceived capabilities combined (health, belief in hard work, and freedom), its contribution to the variance of happiness yesterday is only a third of that of all the perceived capability variables.

Our findings thus far show evidence that evaluative well-being (BPL) is strongly correlated with both sets of capabilities, most notably income, while learning and positive affect are more relevant to hedonic well-being. This conclusion is supported by comparing both the relative influence (i.e., standardized coefficient estimates) and the relative importance (i.e., variance decompositions). These results are in line with the understanding that evaluative well-being better reflects manifestations of autonomy.

[Table 2 here]

Table 3 demonstrates the capabilities-well-being relationship across different world regions. Specifically, we conjecture that there may be cultural differences or regional disparities in the perceptions of opportunities and means and the rates at which people "convert" capabilities to SWB. Some of this variation may result from language and cultural disparities in the interpretation of attitudinal questions related to the importance of hard work or freedom of choice. Following a similar methodology as in Tay 
and Diener (2011), to compare the relative importance of factors across regions, we exclude the country dummies (but keep a linear time trend variable).

[Table 3 here]

The same variables explain as much as 23 percent of the variation in BPL in the world sample and as little as 10 percent of the variation in LAC. Demographic variables contribute to about a fifth of the explained variation in BPL in LAC and as low as 6 percent of the variation in the EU-15. The most notable result relates to the relationship between income and evaluative well-being. While income is the most important predictor of BPL in all regions, it is relatively more important in the world sample (53 percent of the total explained variance) and in transition economies (35 percent) compared with EU-15 and LAC (26 and 28 percent, respectively). While respondents in LAC likely focus less on income because they have less of it to begin with, those in the wealthier EU-15 context have likely shifted their emphasis from basic needs to values related to self-expression and freedom (Inglehart et al., 2008). While health perceptions are equally important in all three regions, accounting for about 10 percent of the total variation, belief in hard work has a greater importance in the transition economies and in the EU-15 than in LAC. Notably, freedom is much more relevant for the evaluative well-being of the more advanced EU15 region (16 percent) than for transition countries ( 8 percent) and LAC (4 percent).

The right panel of Table 3 shows the association between capabilities and means and hedonic well-being (happiness yesterday). It is immediately obvious that smiling yesterday is the most important predictor of hedonic happiness in all regions, most notably in LAC (where it predicts 72 percent of the explained variation in happiness yesterday). Capabilities of both types are most important for happiness yesterday in the EU-15 (17 percent) and least important in LAC (12 percent).

The regional results in Table 3 suggest a pattern across development levels, with respondents in the wealthier EU-15 countries putting a smaller emphasis on income when thinking about their best possible life but a higher emphasis on freedom than respondents in transition economies and LAC. This result is in line with research suggesting that beyond a certain level of development, income matters less 
to SWB, but freedom matters more (Inglehart et al., 2008). In contrast, smiling and personal characteristics have a great importance for the hedonic and evaluative well-being of respondents in poorer regions. Twenty-five years after the fall of the Berlin Wall, citizens in the ex-socialist states value belief in hard work when they think about their lives as a whole, as much as those in the rich EU-15 countries, and value freedom more than those in the less-developed LAC context.

\subsection{Eudaimonic Well-being}

Table 4 shows novel evidence related to the determinants of eudaimonic happiness (defined here as having meaning and purpose in life). The included variables explain only 9 percent of the total variation in eudaimonic well-being, and demographic variables account for less than a quarter (22 percent) of that variation; smiling accounts for another 11 percent. Importantly, capabilities (both objective and perceived) explain a third of the total variation in eudaimonic well-being, with perceived means and freedoms accounting for 29 percent of the total explained variance. Belief in hard work emerges as the most important capability relevant for eudaimonic well-being - surely an intuitive correlation. Income accounts for only two percent of the explained variation in eudaimonic well-being. Interestingly, only involuntary part-time work is statistically significant among the employment variables and is positively correlated with eudaimonic well-being (relative to being out of the labor force), which is a puzzling result worth further explorations. In short, perceived capabilities, personal and family characteristics, and between-country differences are the most important factors associated with meaning and purpose in life.

[Table 4 here]

\subsection{Quantile Regression Results}

To explore whether the same tools and capabilities have a different association with SWB for the happiest and unhappiest individuals, we employ quantile regressions (with BPL as the dependent variable). We report detailed results for five quantiles: $0.10,0.25,0.50$ (median), 0.75, 0.90. We expect that individuals put different weights on the same capabilities and means depending on their position in the subjective well-being distribution. Based on prior research (Binder \& Coad, 2011; 2014), we 
conjecture that the happiest individuals are likely to have high subjective well-being regardless of factors such as income, opportunities, and autonomy and are less likely to emphasize them when they think about their lives as a whole compared with relatively unhappier respondents. We expect that individuals with high levels of SWB are resilient and maintain their SWB levels regardless of capabilities and means.

Table 5 shows that the magnitudes of the coefficient estimates decrease from the $10^{\text {th }}$ quantile (i.e., lowest evaluative well-being) to the $90^{\text {th }}$ quantile (i.e., highest evaluative well-being) for the following capabilities variables: health perceptions, belief in hard work, income, education, voluntary part-time employment, and being unemployed. These results support our conjecture. The coefficient estimate for satisfaction with freedom is highest for Q10, declines monotonically until Q75, and rises slightly in Q90.

\section{[Table 5 here]}

The coefficient estimates for the employment variables reveal the heterogeneity in the relationship between employment status and SWB. The estimate for full-time employment is positive for Q10, declines in magnitude until Q50, is insignificant for Q75, and then becomes negative and statistically significant for Q90. This suggests that while having a full-time job has strong positive effects for those at and below the median of the SWB distribution, at high SWB levels, it decreases one's perceptions of the best possible life. Self-employment, meanwhile, is statistically insignificant below median SWB and becomes negative and statistically significant for Q50, Q75 and Q90, again supporting the hypothesis that happier individuals put a smaller weight on capabilities and means. As in Binder and Coad (2014), being unemployed has the strongest negative effect on the unhappiest quantile and the smallest impact on the happiest, likely because SWB acts as a shield for unfavorable life events, such as losing one's job.

Meanwhile, the coefficient estimate for learning is U-shaped across the quantiles, high for the $10^{\text {th }}$ percent quantile (Q10), decreasing until Q50, and then increasing again for Q75 and Q90, where it is the highest. This suggests that learning (and perhaps creativity), in contrast to the capability variables, is very important for the happiest people, with causality likely running in both directions. Our findings 
corroborate Dolan and Metcalfe's (2012) results that show a positive association between innovation and well-being. Similarly, the coefficient estimate for living in an urban (as opposed to a rural) area increases from Q25 and Q50 to Q90, which is suggestive of Florida's (2004) creative class phenomenon.

\section{5 Negative Hedonic Well-Being}

Health perceptions, belief in hard work, freedom, and income are negatively correlated with stress and anger, with smiling having the greatest contribution to the variance (after country and year differences). All employment categories, including full-time employment, self-employment, and part-time work are positively correlated with stress and anger in transition economies (the reference group is "out of the labor force"). Finally, despite its negligible contribution to the total explained variance, while education is positively associated with stress, it is negatively correlated with anger. Our evidence suggests some capabilities, namely employment status, can enhance SWB in some aspects but also contribute to stress and anger, which has implications for public policy (see Table 6).

\section{Discussion and Conclusion}

The emerging subjective well-being science has the potential to inform about the complexities of the human condition and mechanisms to enhance it. In this paper, we focused on people's capacity to exercise choice and pursue fulfilling lives, which is an important well-being component with implications for development economics. We capture this construct through self-reported objective and perceived variables related to capabilities and means and explored their relation to SWB around the world.

This exploratory study sought answers to three separate but related questions. Are perceived or actual opportunities and means more important for life evaluations or emotional states? Does the SWBopportunities link differ across countries at different levels of development? Do the same tools and capabilities have the same association with evaluative well-being for the happiest and unhappiest citizens?

We find that, in general, capabilities and SWB are related and that both objective and subjective capabilities are relatively more important for life evaluations than positive hedonic well-being (happiness yesterday). This result may be due to the more framed nature of the BPL question or could be attributed to 
unobserved heterogeneity across personalities, which may be more important to hedonic well-being. Positive affect (i.e., smiling), for example, is the most relevant predictor of hedonic happiness.

Capabilities and means have a slightly different relative importance for hedonic and evaluative well-being across different regions of different development levels. When they think about their best possible life, respondents in transition economies place a higher value on income than those in the wealthier EU-15 countries and in Latin America and the Caribbean. Belief in hard work is relatively more important for evaluative well-being in transition economies and the EU-15 than in other regions. Freedom is more important for the best possible life (BPL) of respondents in the most developed EU-15 region. Positive affect (smiling) is more relevant for hedonic happiness in LAC than in either the transition economies or the EU-15.

We also find that most perceived and actual capabilities and means are less important to SWB at the highest levels of the SWB distribution. Overall, respondents at the highest levels of the SWB distribution are least concerned with (or value the least) the proxies for objective capabilities, such as income and education. Full-time employment, for example, is in fact negatively correlated with SWB at the top of the distribution, while unemployment has the strongest negative correlation with BPL for the unhappiest quantile. Our findings indicate, therefore, that the happiest respondents are happy regardless of having perceived or actual capabilities. From a public policy perspective, it is informative to know that investing in the capabilities and means (e.g., health and education) for the least happy individuals can improve their SWB. Finally, our results show that while some capabilities, such as employment status, are positive for subjective well-being (in both its hedonic and evaluative dimensions), they also contribute to negative affect, such as stress and anger.

Eudaimonic well-being, which seeks to capture the extent to which people have purpose or meaning in their lives, is the least studied SWB dimension. We found that individual-level traits, such as positive affect (smiling), perceptions of health, freedom, and belief in hard work, are the most important correlates of this SWB dimension. While our results are preliminary and the direction of causality is 
unclear, there seems to be an interesting link between perceptions of freedom and belief in individual effort and feeling purpose or meaning in life.

Public policy plays an important role in assisting those lacking choice and agency through attempting to equalize opportunities. Our results suggest that what constitutes equal opportunities may have different meaning and value depending on the context, and thus policies which aim to enhance capabilities may have a differential impact on the SWB across different circumstances. Objective capabilities (such as education) are likely to improve the long-term SWB of those lacking agency and, as such, may be reasonable to promote despite the differential weights that different people put on them and their differential impact on subjective well-being. We should note, however, that while policymakers can create environments and institutions conducive to enhancing people's capabilities and freedoms, individuals can choose whether and how to convert these capabilities to SWB. This paper is a first step towards understanding a complex question that is fundamental to human well-being and flourishing. Based on our findings, both Aristotle's and Bentham's conceptions of well-being and happiness help inform our understanding of the development process and enlighten our perspective of how freedoms, means, and opportunities relate to these well-being dimensions. Our results are as complex as the question, yet we hope that they are promising enough to spur further exploration. 


\section{References}

Adler, M., Dolan, P., \& Kavetsos, G. (2014). "Understanding Life Choices: Happiness or Something Else?" Mimeo, London School of Economics.

Adler, M. \& Fleurbaey, M. (forthcoming). Subjective Well-Being and Public Policy. Oxford: Oxford University Press.

Alesina, A., Di Tella, R., \& MacCulloch, R. (2004). Inequality and Happiness: Are Europeans and Americans Different? Journal of Public Economics, 88(9-10), 2009-2042.

Alkire, S. (2002). Dimensions of Human Development. World Development, 30(2), 181-205.

Alkire, S. (2005). Subjective Quantitative Studies of Human Agency. Social Indicators Research, 74(1), 217-260.

Anand, P., Hunter, G., Carter, I., Dowding, K., Guala, F., \& Hees, M. V. (2009). The Development of Capability Indicators. Journal of Human Development and Capabilities, 10(1), 125-152.

Anand, P., Hunter, G., \& Smith, R. (2005). Capabilities and Well-Being: Evidence Based on the SenNussbaum Approach to Welfare. Social Indicators Research, 74(1), 9-55.

Anand, P., Krishnakumar, J., \& Tran, N. B. (2011). Measuring Welfare: Latent Variable Models for Happiness and Capabilities in the Presence of Unobservable Heterogeneity. Journal of Public Economics, 95(3-4), 205-215.

Anand, P., \& van Hees, M. (2006). Capabilities and Achievements: An Empirical Study. The Journal of Socio-Economics, 35(2), 268-284.

Becker, A., Deckers, T., Dohmen, T., Falk, A., \& Kosse, F. (2012). The Relationship Between Economic Preferences and Psychological Personality Measures. Annual Review of Economics, 4(1), 453478.

Blanchflower, D., \& Oswald, A. (2004). Well-being Over Time in the USA and Britain, Journal of Public Economics 88, 1359-87. 
Binder, M., \& Coad, A. (2011). From Average Joe's Happiness to Miserable Jane and Cheerful John: Using Quantile Regressions to Analyze the Full Subjective Well-being Distribution. Journal of Economic Behavior \& Organization, 79(3), 275-290.

Binder, M., \& Coad, A. (2014). Heterogeneity in the Relationship between Unemployment and Subjective Well-Being: A Quantile Approach. Levy Economics Institute of Bard College Working Paper No. $808,1-31$.

Buchinsky, M. (1998). Recent Advances in Quantile Regression Models: A Practical Guideline for Empirical Research. The Journal of Human Resources, 33(1), 88-126.

Cade, B. S., \& Noon, B. R. (2003). A Gentle Introduction to Quantile Regression for Ecologists. Frontiers in Ecology and the Environment, 1(8), 412-420.

Clark, A. E., Frijters, P., \& Shields, M. A. (2008). Relative Income, Happiness, and Utility: An Explanation for the Easterlin Paradox and Other Puzzles. Journal of Economic Literature, 6(1), 95-144.

Conti, G., \& Pudney, S. (2011). Survey Design and the Analysis of Satisfaction. Review of Economics and Statistics, 93(3), 1087-1093.

Crocker, D. A. (2008). Ethics of Global Development: Agency, Capability, and Deliberative Democracy (Kindle ed.). Cambridge: Cambridge University Press.

Crocker, D. A. (2012). Leadership and Global Justice. In D. A. Hicks \& T. Williamson (Eds.), (pp. 4158). Palgrave Macmillan.

Crocker, D. A., \& Robeyns, I. (2009). Capability and Agency. In C. W. Morris (Ed.), Amartya Sen (pp. 60-90). New York: Cambridge University Press.

Deci, E. L., \& Ryan, R. M. (2008). Hedonia, Eudaimonia, and Well-Being: An Introduction. Journal of Happiness Studies, 9(1), 1-11.

Diener, E., Suh, E. M., Lucas, R. E., \& Smith, H. L. (1999). Subjective Well-being: Three Decades of Progress. Psychological Bulletin, 125(2), 276-302. 
Diener, E., Lucas, R., Schimmack, U., \& Helliwell, J. (2009). Well-being for Public Policy. New York: Oxford University Press.

Diener, E., Inglehart, R., \& Tay, L. (2013). Theory and Validity of Life Satisfaction Scales. Social Indicators Research, 112(3), 497-527.

Di Tella, R., \& MacCulloch, R. (2006). Some Uses of Happiness Data in Economics. The Journal of Economic Perspectives, 20(1), 25-46.

Dolan, P., \& Kavetsos, G. (2012). Happy Talk: Mode of Administration Effects on Subjective WellBeing. Centre for Economic Performance Discussion Paper No 1159, 1-17.

Dolan, P., \& Metcalfe, R. (2012). The Relationship between Innovation and Subjective Wellbeing. Research Policy, 41(8), 1489-1498.

Durand, M., \& Smith, C. (2013). The OECD Approach to Measuring Subjective Well-being. In J. F. Helliwell, R. Layard \& J. Sachs (Eds.), World Happiness Report 2013 (pp. 112-137).

Easterlin, R. A. (1995). Will Raising the Incomes of All Increase the Happiness of All? Journal of Economic Behavior \& Organization, 27(1), 35-47.

Ferrer-i-Carbonell, A., \& Frijters, P. (2004). How Important Is Methodology for the Estimates of the Determinants of Happiness?. The Economic Journal, 114(497), 641-659.

Fields, G. S. (2003). Accounting for Income Inequality and Its Change: A New Method, with Application to the Distribution of Earnings in the United States. Research in labor economics, 22, 1-38.

Fields, G. S. (2004). Regression-Based Decompositions: A New Tool for Managerial Decision-Making. Department of Labor Economics, Cornell University, 1-41.

Fiorio, C. V., \& Jenkins, S. P. (2010). Ineqrbd: Stata Module to Calculate Regression-Based Inequality Decomposition. Statistical Software Components.

Florida, R. (2004). The Rise of the Creative Class: And How It's Transforming Work, Leisure, Community and Everyday Life. New York, NY: Basic Books.

Frey, B. S., \& Stutzer, A. (2002). What Can Economists Learn from Happiness Research?. Journal of Economic literature, 40(2), 402-435. 
Graham, C. (2008). Happiness And Health: Lessons And Questions For Public Policy. Health Affairs, 27(1), 72-87.

Graham, C. (2011). The Pursuit of Happiness: An Economy of Well-Being. Washington, D.C.: The Brookings Institution Press.

Graham, C., \& Pettinato, S. (2002). Frustrated Achievers: Winners, Losers and Subjective Well-Being in New Market Economies. The Journal of Development Studies, 38(4), 100-140.

Graham, C., \& Lora, E. (Eds.). (2009). Paradox and Perception: Measuring Quality of Life in Latin America. Washington, D.C.: Brookings Institution Press.

Graham, C., Chattopadhyay, S., \& Picon, M. (2010). The Easterlin and Other Paradoxes: Why Both Sides of the Debate May Be Correct. In E. Diener, D. Kahneman \& J. F. Helliwell (Eds.), International Differences in Well-Being (Positive Psychology) (pp. 247-290). Oxford: Oxford University Press.

Graham, C., \& Chattopadhyay, S. (2013). Gender and Well-Being around the World. International Journal of Happiness and Development, 1(2), 212-232.

Graham, C., \& Nikolova, M. (2013). Does Access to Information Technology Make People Happier? Insights from Well-being Surveys from Around the World. The Journal of Socio-Economics, 44(0), 126-139.

Hall, J. (2013). From Capabilities to Contentment: Testing the Links between Human Development and Life Satisfaction. In J. F. Helliwell, R. Layard \& J. Sachs (Eds.), World Happiness Report 2013, (pp. 138-153).

Helliwell, J. F., Barrington-Leigh, C. P., Harris, A., \& Huang, H. (2010). International Evidence on the Social Context of Well-Being. In J. F. H. E. Diener, and D. Kahneman (Ed.), International Differences in Well-Being. New York: Oxford University Press.

Helliwell, J. F., Layard, R., \& Sachs, J. D. (2013). Introduction. In J. F. Helliwell, R. Layard \& J. Sachs (Eds.), World Happiness Report 2013 (pp. 2-7).

Inglehart, R., Foa, R., Peterson, C., \& Welzel, C. (2008). Development, Freedom, and Rising Happiness: A Global Perspective (1981-2007). Perspectives on Psychological Science, 3(4), 264-285. 
Kahneman, D., \& Krueger, A. B. (2006). Developments in the Measurement of Subjective Well-Being. Journal of Economic Perspectives, 20(1), 3-24.

Kahneman, D., \& Deaton, A. (2010). High Income Improves Evaluation of Life but Not Emotional WellBeing. Proceedings of the National Academy of Sciences, 107(38), 16489-16493.

Koenker, R., \& Bassett, G., Jr. (1978). Regression Quantiles. Econometrica, 46(1), 33-50.

Koenker, R., \& Hallock, K. F. (2001). Quantile Regression. The Journal of Economic Perspectives, 15(4), 143-156.

Krueger, A. B., \& Schkade, D. A. (2008). The Reliability of Subjective Well-being Measures. Journal of Public Economics, 92(8), 1833-1845.

Menard, S. (2004). Six Approaches to Calculating Standardized Logistic Regression Coefficients. The American Statistician, 58(3), 218-223.

Muffels, R., \& Headey, B. (2013). Capabilities and Choices: Do They Make Sen'se for Understanding Objective and Subjective Well-Being? An Empirical Test of Sen's Capability Framework on German and British Panel Data. Social Indicators Research, 110(3), 1159-1185.

Neumayer, E., Plümper, T., \& Barthel, F. (2014). The Political Economy of Natural Disaster Damage. Global Environmental Change, 24(0), 8-19.

Nussbaum, M. C. (2011). Creating Capabilities: The Human Development Approach: Belknap Press of Harvard University Press.

O'Donnell, G. (2013). Using Well-Being as a Guide to Policy. In J. F. Helliwell, R. Layard \& J. Sachs (Eds.), World Happiness Report 2013 (pp. 98-111).

OECD. (2011). How's Life?: Measuring Well-being, OECD Publishing. Retrieved November 24, 2013, from http://dx.doi.org/10.1787/9789264121164-en

OECD. (2013). OECD Guidelines on Measuring Subjective Well-being, OECD Publishing. Retrieved May 18, 2014 from http://dx.doi.org/10.1787/9789264191655-en

Ramos, X., \& Silber, J. (2005). On the Application of Efficiency Analysis to the Study of the Dimensions of Human Development. Review of Income and Wealth, 51(2), 285-309. 
Robeyns, I. (2005). Selecting Capabilities for Quality of Life Measurement. Social Indicators Research, 74(1), 191-215.

Schutte, L., Wissing, M., \& Khumalo, I. (2013). Further Validation of the Questionnaire for Eudaimonic Well-Being (QEWB). Psychology of Well-Being: Theory, Research and Practice, 3(1), 1-22.

Sen, A. (1985). Well-Being, Agency and Freedom: The Dewey Lectures 1984. The Journal of Philosophy, 82(4), 169-221.

Sen, A. (1999). Development as Freedom. New York, NY: Anchor Books.

Senik, C. (2009). Direct Evidence on Income Comparisons and Their Welfare Effects. Journal of Economic Behavior \& Organization, 72(1), 408-424.

Simon, J., Anand, P., Gray, A., Rugkåsa, J., Yeeles, K., \& Burns, T. (2013). Operationalising the Capability Approach for Outcome Measurement in Mental Health Research. Social Science \& Medicine, 98, 187-196.

Stone, A. A., \& Mackie, C. (2014). Subjective Well-Being: Measuring Happiness, Suffering, and Other Dimensions of Experience: National Academies Press.

Tay, L.,\& Diener, E. (2011). Needs and Subjective Well-being around the World. Journal of Personality and Social Psychology, 101 (2), 354-365.

Van Ootegem, L., \& Spillemaeckers, S. (2010). With a Focus on Well-being and Capabilities. The Journal of Socio-Economics, 39(3), 384-390.

Veenhoven, R. (2000). Freedom and Happiness: A Comparative Study in 46 Nations in the Early 1990s. In E. Diener \& E. M. Suh (Eds.), Culture and Subjective Well-being (pp. 257-288). Cambridge, MA: MIT Press.

Veenhoven, R. (2010). Capability and Happiness: Conceptual Difference and Reality Links. The Journal of Socio-Economics, 39(3), 344-350.

Verme, P. (2009). Happiness, Freedom and Control. Journal of Economic Behavior \& Organization, $71(2), 146-161$. 
Waterman, A., Schwartz, S., Zamboanga, B., Ravert, R., Williams, M., Agocha, M., et al. (2010). The Questionnaire for Eudaimonic Well-Being: Psychometric Properties, Demographic Comparisons, and Evidence of Validity. The Journal of Positive Psychology, 5(1), 41 - 61.

White, M. P., \& Dolan, P. (2009). Accounting for the Richness of Daily Activities. Psychological Science, 20(8), 1000-1008. 
Figures and Tables

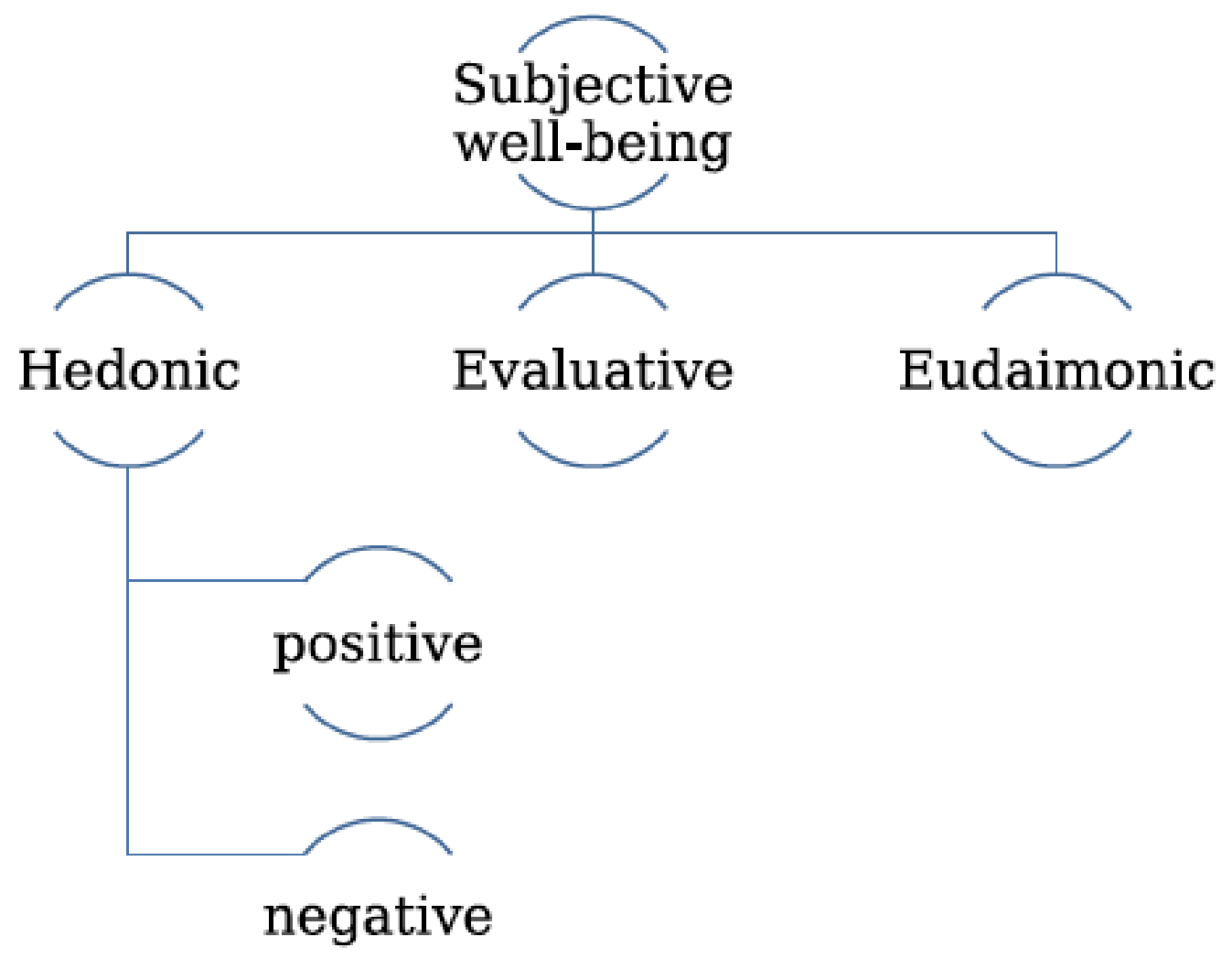

Figure 1: Subjective Well-being Dimensions

Source: Authors 


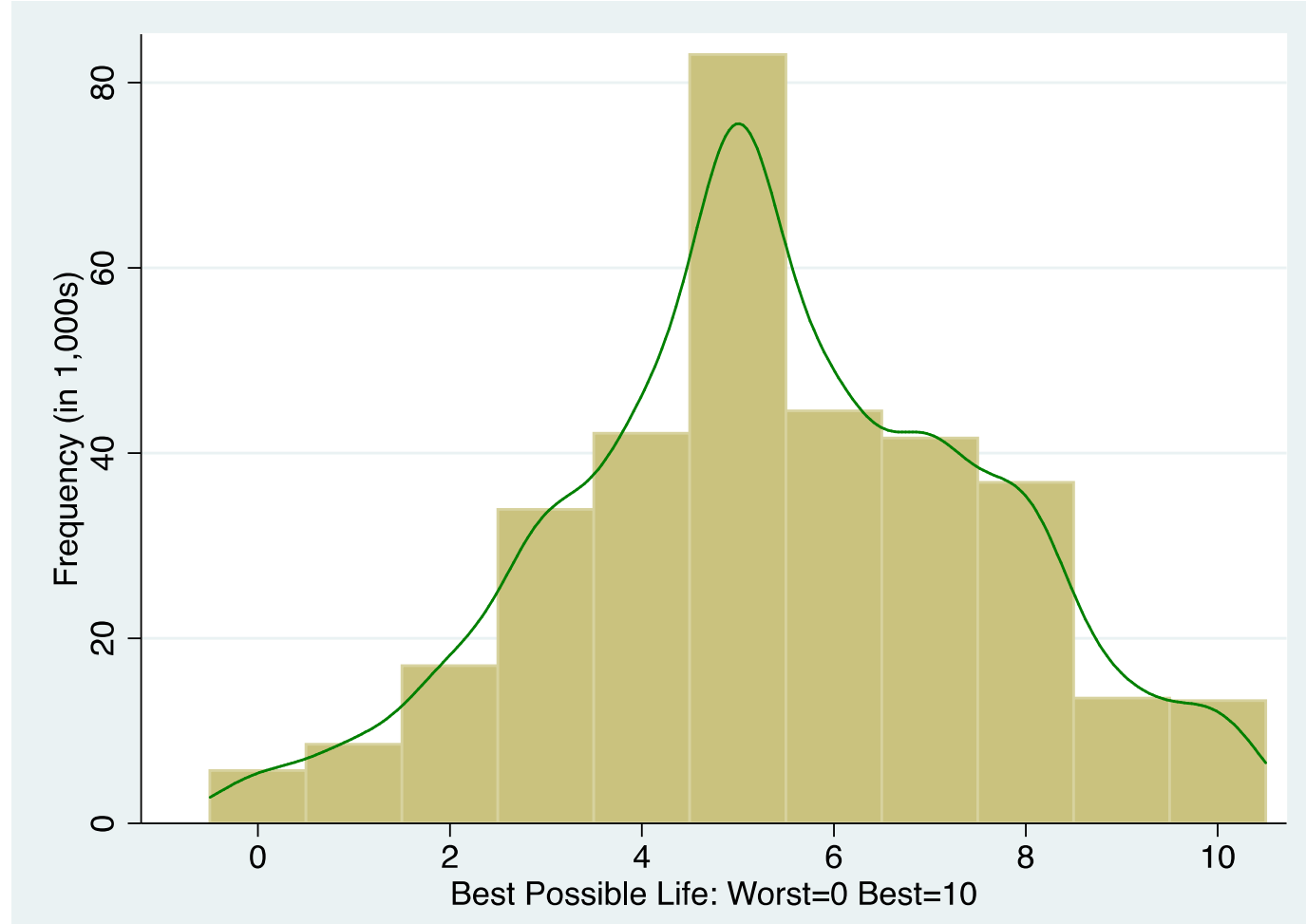

Figure 2: Histogram of the Best Possible Life variable (BPL), World Sample Source: Gallup World Poll. 


\begin{tabular}{|c|c|c|c|c|c|c|c|c|}
\hline \multirow[b]{2}{*}{ Variable } & \multicolumn{2}{|c|}{ World, $\mathrm{N}=339,933$} & \multicolumn{2}{|c|}{ Transition, $\mathrm{N}=61,436$} & \multicolumn{2}{|c|}{$\mathrm{EU}-15, \mathrm{~N}=33,117$} & \multicolumn{2}{|c|}{ LAC, $\mathrm{N}=49,849$} \\
\hline & Mean & Std.Dev. & Mean & Std.Dev. & Mean & Std.Dev. & Mean & Std.Dev. \\
\hline \multicolumn{9}{|l|}{ Dependent Variables } \\
\hline Best Possible Life $(0=$ Worst, $10=$ Best $)$ & 5.398 & 2.200 & 5.177 & 2.055 & 6.881 & 1.915 & 6.159 & 2.405 \\
\hline Experienced Happiness Yesterday $(1=$ Yes $)$ & 0.711 & 0.453 & 0.566 & 0.496 & 0.772 & 0.420 & 0.811 & 0.392 \\
\hline Experienced Stress Yesterday (1=Yes) & 0.282 & 0.450 & 0.223 & 0.416 & 0.335 & 0.472 & 0.319 & 0.466 \\
\hline Experienced Anger Yesterday $(1=\mathrm{Yes})$ & 0.186 & 0.389 & 0.198 & 0.398 & 0.158 & 0.364 & 0.168 & 0.374 \\
\hline \multicolumn{9}{|l|}{ Perceptions of Capabilities and Means } \\
\hline No Health Problem (1=Yes) & 0.756 & 0.430 & 0.694 & 0.461 & 0.785 & 0.411 & 0.771 & 0.420 \\
\hline Belief in Hard Work for Getting Ahead ( $1=$ Yes) & 0.808 & 0.394 & 0.591 & 0.492 & 0.800 & 0.400 & 0.871 & 0.335 \\
\hline Satisfied with Freedom in Life (1=Yes) & 0.725 & 0.447 & 0.639 & 0.480 & 0.840 & 0.366 & 0.776 & 0.417 \\
\hline \multicolumn{9}{|l|}{ Objective Capabilities and Means } \\
\hline Some College/College Diploma ( $1=$ Yes $)$ & 0.136 & 0.343 & 0.199 & 0.399 & 0.255 & 0.436 & 0.106 & 0.308 \\
\hline Household Income (in ID) & 14,571 & 23,750 & 12,419 & 13,231 & 41,667 & 39,817 & 10,003 & 11,031 \\
\hline \multicolumn{9}{|l|}{ Employment Categories } \\
\hline Employed Full-Time (1=Yes) & 0.264 & 0.441 & 0.338 & 0.473 & 0.389 & 0.488 & 0.254 & 0.435 \\
\hline Self-Employed (1=Yes) & 0.146 & 0.353 & 0.083 & 0.277 & 0.057 & 0.232 & 0.123 & 0.328 \\
\hline Voluntarily Employed Part-Time ( $1=$ Yes) & 0.073 & 0.260 & 0.060 & 0.237 & 0.075 & 0.264 & 0.064 & 0.246 \\
\hline Unemployed (1=Yes) & 0.063 & 0.243 & 0.060 & 0.237 & 0.047 & 0.213 & 0.073 & 0.261 \\
\hline Employed Part-Time, Wants Full-Time ( $1=$ Yes) & 0.074 & 0.262 & 0.051 & 0.220 & 0.046 & 0.210 & 0.084 & 0.278 \\
\hline Out of the Labor Force (1=Yes) & 0.379 & 0.485 & 0.408 & 0.492 & 0.384 & 0.486 & 0.402 & 0.490 \\
\hline \multicolumn{9}{|l|}{ Control Variables } \\
\hline Age & 40.337 & 16.968 & 44.847 & 17.930 & 49.632 & 16.171 & 40.490 & 17.514 \\
\hline Female $(1=$ Yes $)$ & 0.534 & 0.499 & 0.589 & 0.492 & 0.562 & 0.496 & 0.568 & 0.495 \\
\hline Married (1=Yes) & 0.594 & 0.491 & 0.582 & 0.493 & 0.615 & 0.487 & 0.538 & 0.499 \\
\hline Urban Area (1=Yes) & 0.406 & 0.491 & 0.384 & 0.486 & 0.427 & 0.495 & 0.578 & 0.494 \\
\hline Child in Household ( $1=$ Yes) & 0.555 & 0.497 & 0.387 & 0.487 & 0.278 & 0.448 & 0.583 & 0.493 \\
\hline Household Size & 3.235 & 1.883 & 2.789 & 1.426 & 2.186 & 1.062 & 2.933 & 1.462 \\
\hline Religion Important ( $1=$ Yes) & 0.740 & 0.439 & 0.577 & 0.494 & 0.382 & 0.486 & 0.813 & 0.390 \\
\hline Smiled Yesterday $(1=$ Yes $)$ & 0.717 & 0.450 & 0.596 & 0.491 & 0.777 & 0.416 & 0.845 & 0.362 \\
\hline Learned Yesterday ( $1=$ Yes $)$ & 0.515 & 0.500 & 0.399 & 0.490 & 0.589 & 0.492 & 0.648 & 0.478 \\
\hline
\end{tabular}

Source: Gallup World Poll.

Notes: All statistics are for 2009-2012 and show the number of observations, means, and standard deviations for each variable. Best Possible Life measures the respondent's assessment of her current life relative to her best possible life on a scale of 0 to 10 , where 0 is the worst possible life, and 10 is the best possible life. Experienced Happiness Yesterday, Stress Yesterday, Anger Yesterday, and Smiled Yesterday are binary variables coded as 1 if the respondent experienced this type of affect the day before and 0 otherwise. Household income is in international dollars (ID), which allows comparisons across countries and time. 
Table 2: Relative Influence and Relative Importance, Best Possible Life and Happiness Yesterday, World Sample

\begin{tabular}{|c|c|c|c|c|c|c|c|c|}
\hline & \multicolumn{4}{|c|}{ BPL, $R^{2}=0.303$} & \multicolumn{4}{|c|}{ Happiness Yesterday, $\mathrm{R}^{2}=0.251$} \\
\hline & $\begin{array}{l}\text { Unstd. } \\
\text { Coeff. }\end{array}$ & t-stat & $\begin{array}{c}\text { Std. } \\
\text { Coeff. }\end{array}$ & $\begin{array}{c}\text { Contribution to } \\
\text { Variance }(\%)\end{array}$ & $\begin{array}{l}\text { Unstd. } \\
\text { Coeff. }\end{array}$ & t-stat & Std. Coeff. & $\begin{array}{c}\text { Contribution } \\
\text { to Variance } \\
(\%)\end{array}$ \\
\hline No Health Problem & 0.361 & 44.424 & 0.070 & 3.223 & 0.059 & 34.284 & 0.056 & 2.910 \\
\hline Belief in Hard Work & 0.322 & 36.078 & 0.058 & 1.534 & 0.051 & 25.442 & 0.044 & 2.338 \\
\hline Freedom & 0.319 & 41.606 & 0.065 & 3.374 & 0.06 & 35.316 & 0.059 & 3.565 \\
\hline Some College/College & & & & & & & & \\
\hline Diploma & 0.370 & 39.074 & 0.058 & 3.485 & 0.008 & 3.784 & 0.006 & 0.078 \\
\hline Log Household Income & 0.310 & 71.374 & 0.202 & 26.669 & 0.019 & 27.168 & 0.061 & 2.568 \\
\hline Full-Time Employee & 0.051 & 5.512 & 0.010 & 0.501 & -0.01 & -5.258 & -0.01 & -0.098 \\
\hline Self-Employed & -0.040 & -3.742 & -0.007 & 0.159 & -0.001 & -0.293 & -0.001 & -0.001 \\
\hline Voluntary Part-Time & 0.114 & 8.864 & 0.014 & 0.045 & 0.005 & 1.903 & 0.003 & 0.011 \\
\hline Unemployed & -0.342 & -22.516 & -0.038 & 0.868 & -0.039 & -12.593 & -0.021 & 0.266 \\
\hline Involuntary Part-Time & -0.153 & -11.250 & -0.018 & 0.352 & -0.012 & -4.143 & -0.007 & 0.005 \\
\hline Smiled Yesterday & 0.405 & 53.369 & 0.083 & 5.195 & 0.333 & 178.363 & 0.331 & 54.853 \\
\hline Learned Yesterday & 0.327 & 47.497 & 0.074 & 4.321 & 0.102 & 67.405 & 0.112 & 11.014 \\
\hline Demographic Variables & Yes & Yes & Yes & 2.643 & Yes & Yes & Yes & 2.118 \\
\hline Country and Year Dummies & Yes & Yes & Yes & 47.632 & Yes & Yes & Yes & 20.374 \\
\hline
\end{tabular}

Source: Gallup World Poll.

Notes: $\mathrm{N}=339,933$. All regressions are for 2009-2012. BPL measures the respondent's assessment of her current life relative to her best possible life on a scale of 0 to 10, where 0 is the worst possible life, and 10 is the best possible life. Happiness yesterday is coded as 1 if the respondent experienced this type of affect the previous day and 0 otherwise. Household income is log-transformed and is in international dollars (ID), which allows comparisons across countries and time. Total $\mathrm{R}^{2}$ represents the total amount of variance in the dependent variable explained by the independent variables. Relative importance values sum to 100 percent, representing the proportional contribution of each variable. 
Table 3: Relative Importance of Capabilities and Means Across Regions

\begin{tabular}{|c|c|c|c|c|c|c|c|c|}
\hline & \multicolumn{4}{|c|}{ BPL } & \multicolumn{4}{|c|}{ Happiness Yesterday } \\
\hline & World & Transition & EU-15 & LAC & World & Transition & EU-15 & LAC \\
\hline No Health Problem & 4.519 & 10.155 & 9.845 & 11.935 & 3.519 & 4.791 & 2.124 & 4.039 \\
\hline Belief in Hard Work & 2.473 & 7.701 & 8.916 & 1.542 & 3.582 & 2.880 & 4.074 & 1.611 \\
\hline Freedom & 5.670 & 8.457 & 15.814 & 4.334 & 5.466 & 4.586 & 6.867 & 4.691 \\
\hline Some College/College & & & & & & & & \\
\hline Diploma & 4.341 & 3.144 & 4.110 & 4.150 & -0.016 & -0.020 & -0.104 & 0.141 \\
\hline Log Household Income & 53.357 & 34.895 & 25.597 & 27.987 & 3.567 & 2.291 & 3.186 & 1.561 \\
\hline Full-Time Employee & 1.136 & 1.136 & 0.664 & 2.927 & -0.189 & -0.522 & -0.426 & -0.016 \\
\hline Self-Employed & 0.616 & 0.096 & 0.023 & 1.401 & 0.010 & 0.110 & -0.013 & 0.002 \\
\hline Voluntary Part-Time & 0.053 & 0.295 & 1.575 & 0.089 & 0.012 & 0.030 & 0.433 & 0.011 \\
\hline Unemployed & 1.065 & 1.971 & 4.431 & 4.175 & 0.331 & 0.511 & 0.734 & 0.314 \\
\hline Involuntary Part-Time & 0.598 & 0.120 & 0.286 & 1.969 & 0.005 & 0.002 & 0.011 & 0.003 \\
\hline Smiled Yesterday & 8.377 & 11.965 & 13.362 & 11.053 & 66.964 & 53.254 & 63.670 & 72.432 \\
\hline Learned Yesterday & 7.013 & 9.386 & 9.405 & 8.375 & 14.293 & 17.841 & 14.152 & 11.317 \\
\hline Time Trend & 0.247 & 0.557 & -0.041 & 0.776 & 0.013 & 0.250 & 0.066 & 0.003 \\
\hline Demographic Variables & 10.537 & 10.122 & 6.016 & 19.551 & 2.446 & 13.997 & 5.224 & 3.893 \\
\hline $\mathrm{R}^{2}$ & 0.231 & 0.219 & 0.220 & 0.103 & 0.216 & 0.220 & 0.183 & 0.160 \\
\hline
\end{tabular}

Source: Gallup World Poll.

Notes: Notes: All regressions are for 2009-2012. Best Possible Life measures the respondent's assessment of her current life relative to her best possible life on a scale of 0 to 10 , where 0 is the worst possible life, and 10 is the best possible life. Happiness yesterday is coded as 1 if the respondent experienced this type of affect the previous day and 0 otherwise. Household income is log-transformed and is in international dollars (ID), which allows comparisons across countries and time. Total $\mathrm{R}^{2}$ represents the total amount of variance in the dependent variable explained by the independent variables. Relative importance values sum to 100 percent, representing the proportional contribution of each variable. LAC $=$ Latin America and the Caribbean. The number of observations is as follows: World: 342,385; Transition Economies: 61,436; EU-15: 33,117; LAC: 49,849 . 
Table 4: Relative Influence and Relative Importance, Meaning and Purpose in Life

\begin{tabular}{|c|c|c|c|c|}
\hline & \multicolumn{4}{|c|}{ All Available Countries, $\mathrm{R}^{2}=0.094$} \\
\hline & $\begin{array}{l}\text { Unstd. } \\
\text { Coeff. }\end{array}$ & t-stat & $\begin{array}{l}\text { Std. } \\
\text { Coeff. }\end{array}$ & $\begin{array}{c}\text { Contribution to Variance } \\
(\%)\end{array}$ \\
\hline No Health Problem & 0.031 & 6.218 & 0.050 & 5.856 \\
\hline Belief in Hard Work & 0.053 & 10.908 & 0.094 & 16.570 \\
\hline Freedom & 0.031 & 7.367 & 0.057 & 6.585 \\
\hline Some College/College & & & & \\
\hline Diploma & 0.011 & 1.754 & 0.012 & 0.415 \\
\hline Log Household Income & 0.013 & 6.058 & 0.058 & 1.571 \\
\hline Full-Time Employee & 0.010 & 1.838 & 0.016 & 0.579 \\
\hline Self-Employed & 0.009 & 1.519 & 0.012 & 0.559 \\
\hline Voluntary Part-Time & 0.012 & 1.257 & 0.009 & 0.088 \\
\hline Unemployed & 0.017 & 1.855 & 0.013 & 0.141 \\
\hline Involuntary Part-Time & 0.016 & 2.462 & 0.019 & 0.456 \\
\hline Smiled Yesterday & 0.039 & 8.608 & 0.069 & 10.611 \\
\hline Learned Yesterday & 0.026 & 6.444 & 0.048 & 5.529 \\
\hline Demographic Variables & Yes & Yes & Yes & 21.628 \\
\hline Country and Year Dummies & Yes & Yes & Yes & 29.412 \\
\hline
\end{tabular}

Source: Gallup World Poll.

Notes: $\mathrm{N}=19,288$. All regressions are for 2009-2011. Meaning and purpose in life is a binary variable. Household income is log-transformed and is in international dollars (ID), which allows comparisons across countries and time. Total $\mathrm{R}^{2}$ represents the total amount of variance in the dependent variable explained by the independent variables. Relative importance values sum to 100 percent, representing the proportional contribution of each variable. 
Table 5: Best Possible Life Quantile Regressions, World Sample

\begin{tabular}{|c|c|c|c|c|c|}
\hline & $\begin{array}{l}(1) \\
\text { Q10 }\end{array}$ & $\begin{array}{c}(2) \\
\text { Q25 }\end{array}$ & $\begin{array}{c}(3) \\
\text { Q50 }\end{array}$ & $\begin{array}{c}(4) \\
\text { Q75 }\end{array}$ & $\begin{array}{c}(5) \\
\text { Q90 }\end{array}$ \\
\hline No Health Problem & $\begin{array}{c}0.482 * * * \\
(0.015)\end{array}$ & $\begin{array}{c}0.412 * * * \\
(0.011)\end{array}$ & $\begin{array}{c}0.309 * * * \\
(0.008)\end{array}$ & $\begin{array}{c}0.282 * * * \\
(0.008)\end{array}$ & $\begin{array}{c}0.257 * * * \\
(0.020)\end{array}$ \\
\hline Belief in Hard Work & $\begin{array}{c}0.400 * * * \\
(0.017)\end{array}$ & $\begin{array}{c}0.374 * * * \\
(0.012)\end{array}$ & $\begin{array}{c}0.314^{* * * *} \\
(0.013)\end{array}$ & $\begin{array}{c}0.275^{* * *} \\
(0.014)\end{array}$ & $\begin{array}{c}0.247 * * * \\
(0.013)\end{array}$ \\
\hline Freedom & $\begin{array}{c}0.366^{* * * *} \\
(0.011)\end{array}$ & $\begin{array}{c}0.340 * * * \\
(0.009)\end{array}$ & $\begin{array}{c}0.291 * * * \\
(0.010)\end{array}$ & $\begin{array}{c}0.274 * * * \\
(0.008)\end{array}$ & $\begin{array}{c}0.283 * * * \\
(0.013)\end{array}$ \\
\hline Some College/College Diploma & $\begin{array}{c}0.435 * * * \\
(0.020)\end{array}$ & $\begin{array}{c}0.399 * * * \\
(0.014)\end{array}$ & $\begin{array}{c}0.337 * * * \\
(0.010)\end{array}$ & $\begin{array}{c}0.283 * * * \\
(0.014)\end{array}$ & $\begin{array}{c}0.183 * * * \\
(0.013)\end{array}$ \\
\hline Log Household Income & $\begin{array}{c}0.514 * * * \\
(0.007)\end{array}$ & $\begin{array}{c}0.453 * * * \\
(0.005)\end{array}$ & $\begin{array}{c}0.355^{* * *} \\
(0.004)\end{array}$ & $\begin{array}{c}0.272 * * * \\
(0.005)\end{array}$ & $\begin{array}{c}0.189 * * * \\
(0.006)\end{array}$ \\
\hline \multicolumn{6}{|c|}{ Employment Categories (Ref. Group: Out of the Labor Force) } \\
\hline Full-Time Employee & $\begin{array}{c}0.116^{* * *} \\
(0.012)\end{array}$ & $\begin{array}{c}0.063 * * * \\
(0.011)\end{array}$ & $\begin{array}{c}0.034 * * * \\
(0.009)\end{array}$ & $\begin{array}{c}0.002 \\
(0.009)\end{array}$ & $\begin{array}{c}-0.047 * * \\
(0.016)\end{array}$ \\
\hline Self-Employed & $\begin{array}{l}-0.004 \\
(0.021)\end{array}$ & $\begin{array}{l}-0.017 \\
(0.013)\end{array}$ & $\begin{array}{c}-0.024 * * \\
(0.012)\end{array}$ & $\begin{array}{c}-0.062 * * * \\
(0.012)\end{array}$ & $\begin{array}{c}-0.077 * * * \\
(0.017)\end{array}$ \\
\hline Voluntary Part-Time & $\begin{array}{c}0.186 * * * \\
(0.019)\end{array}$ & $\begin{array}{c}0.141 * * * \\
(0.015)\end{array}$ & $\begin{array}{c}0.098 * * * \\
(0.014)\end{array}$ & $\begin{array}{c}0.072 * * * \\
(0.014)\end{array}$ & $\begin{array}{l}0.048^{*} \\
(0.026)\end{array}$ \\
\hline Unemployed & $\begin{array}{c}-0.422 * * * \\
(0.028)\end{array}$ & $\begin{array}{c}-0.363 * * * \\
(0.020)\end{array}$ & $\begin{array}{c}-0.327 * * * \\
(0.015)\end{array}$ & $\begin{array}{c}-0.287 * * * \\
(0.019)\end{array}$ & $\begin{array}{c}-0.247 * * * \\
(0.040)\end{array}$ \\
\hline Involuntary Part-Time & $\begin{array}{c}-0.156^{* * *} \\
(0.025)\end{array}$ & $\begin{array}{c}-0.158 * * * \\
(0.015)\end{array}$ & $\begin{array}{c}-0.139 * * * \\
(0.017)\end{array}$ & $\begin{array}{c}-0.123 * * * \\
(0.014)\end{array}$ & $\begin{array}{c}-0.129 * * * \\
(0.026)\end{array}$ \\
\hline Smiled Yesterday & $\begin{array}{c}0.384 * * * \\
(0.011)\end{array}$ & $\begin{array}{c}0.395 * * * \\
(0.010)\end{array}$ & $\begin{array}{c}0.375^{* * * *} \\
(0.008)\end{array}$ & $\begin{array}{c}0.370^{* * *} \\
(0.007)\end{array}$ & $\begin{array}{c}0.421 * * * \\
(0.014)\end{array}$ \\
\hline Learned Yesterday & $\begin{array}{c}0.313 * * * \\
(0.012)\end{array}$ & $\begin{array}{c}0.307 * * * \\
(0.009)\end{array}$ & $\begin{array}{c}0.288 * * * \\
(0.008)\end{array}$ & $\begin{array}{c}0.318^{* * *} \\
(0.008)\end{array}$ & $\begin{array}{c}0.334 * * * \\
(0.016)\end{array}$ \\
\hline
\end{tabular}




\begin{tabular}{|c|c|c|c|c|c|}
\hline & $\begin{array}{c}\text { (1) } \\
\text { Q10 }\end{array}$ & $\begin{array}{c}(2) \\
\text { Q25 }\end{array}$ & $\begin{array}{c}(3) \\
\text { Q50 }\end{array}$ & $\begin{array}{c}\text { (4) } \\
\text { Q75 }\end{array}$ & $\begin{array}{c}(5) \\
\text { Q90 }\end{array}$ \\
\hline Age & $\begin{array}{c}-0.026 * * * \\
(0.002)\end{array}$ & $\begin{array}{c}-0.023 * * * \\
(0.002)\end{array}$ & $\begin{array}{c}-0.027 * * * \\
(0.002)\end{array}$ & $\begin{array}{c}-0.032 * * * \\
(0.002)\end{array}$ & $\begin{array}{c}-0.036 * * * \\
(0.002)\end{array}$ \\
\hline Age Squared/100 & $\begin{array}{c}0.021 * * * \\
(0.003)\end{array}$ & $\begin{array}{c}0.018 * * * \\
(0.002)\end{array}$ & $\begin{array}{c}0.023 * * * \\
(0.002)\end{array}$ & $\begin{array}{c}0.030 * * * \\
(0.002)\end{array}$ & $\begin{array}{c}0.038 * * * \\
(0.002)\end{array}$ \\
\hline Female & $\begin{array}{c}0.101 * * * \\
(0.012)\end{array}$ & $\begin{array}{c}0.074 * * * \\
(0.008)\end{array}$ & $\begin{array}{c}0.074 * * * \\
(0.008)\end{array}$ & $\begin{array}{c}0.072 * * * \\
(0.010)\end{array}$ & $\begin{array}{c}0.094 * * * \\
(0.012)\end{array}$ \\
\hline Married or in Civil Partnership & $\begin{array}{c}0.134 * * * \\
(0.016)\end{array}$ & $\begin{array}{c}0.102 * * * \\
(0.010)\end{array}$ & $\begin{array}{c}0.095 * * * \\
(0.010)\end{array}$ & $\begin{array}{c}0.105 * * * \\
(0.010)\end{array}$ & $\begin{array}{c}0.081 * * * \\
(0.015)\end{array}$ \\
\hline Urban Area & $\begin{array}{c}0.089 * * * \\
(0.014)\end{array}$ & $\begin{array}{c}0.118 * * * \\
(0.009)\end{array}$ & $\begin{array}{c}0.129 * * * \\
(0.010)\end{array}$ & $\begin{array}{c}0.150 * * * \\
(0.010)\end{array}$ & $\begin{array}{c}0.161 * * * \\
(0.013)\end{array}$ \\
\hline Child in Household & $\begin{array}{c}-0.141 * * * \\
(0.0136)\end{array}$ & $\begin{array}{c}-0.138 * * * \\
(0.010)\end{array}$ & $\begin{array}{c}-0.129 * * * \\
(0.009)\end{array}$ & $\begin{array}{c}-0.123 * * * \\
(0.008)\end{array}$ & $\begin{array}{c}-0.097 * * * \\
(0.014)\end{array}$ \\
\hline Household Size & $\begin{array}{c}-0.013 * * * \\
(0.003)\end{array}$ & $\begin{array}{c}-0.005 * * \\
(0.002)\end{array}$ & $\begin{array}{c}0.003 \\
(0.002)\end{array}$ & $\begin{array}{c}0.005 * * \\
(0.002)\end{array}$ & $\begin{array}{c}0.012 * * * \\
(0.003)\end{array}$ \\
\hline Religion Important & $\begin{array}{c}-0.072 * * * \\
(0.014)\end{array}$ & $\begin{array}{c}-0.019 * * \\
(0.009)\end{array}$ & $\begin{array}{c}0.012 \\
(0.008)\end{array}$ & $\begin{array}{c}0.055 * * * \\
(0.009)\end{array}$ & $\begin{array}{c}0.120 * * * \\
(0.014)\end{array}$ \\
\hline Year Dummies & Yes & Yes & Yes & Yes & Yes \\
\hline Country Dummies & Yes & Yes & Yes & Yes & Yes \\
\hline Observations & 339,933 & 339,933 & 339,933 & 339,933 & 339,933 \\
\hline Pseudo $\mathrm{R}^{2}$ & 0.1717 & 0.179 & 0.180 & 0.194 & 0.151 \\
\hline
\end{tabular}

Source: Gallup World Poll.

Notes: All quantile regressions are for 2009-2012 and use bootstrapped standard errors (with 100 replications). The dependent variable is BPL, which measures respondents' assessments of their current life relative to the best possible life they can imagine on a scale of 0 (worst possible life) to 10 (best possible life). Q10 corresponds to the 10th percent quantile, Q25 is the 25th percent quantile, Q50 is the 50th percent quantile (median), Q75 is the 75th percent quantile, and Q90 is the 90th percent quantile. Household income is log-transformed and in international dollars (ID), which allows comparisons across countries and time. The table reports the pseudo $\mathrm{R}^{2}$ for each quantile regression.

$* * * \mathrm{p}<0.01, * * \mathrm{p}<0.05, * \mathrm{p}<0.1$ 
Table 6: Relative Influence and Relative Importance, Stress and Anger, World Sample

\begin{tabular}{|c|c|c|c|c|c|c|c|c|}
\hline & \multicolumn{4}{|c|}{ Stress, $\mathrm{R}^{2}=0.114$} & \multicolumn{4}{|c|}{ Anger, $\mathrm{R}^{2}=0.072$} \\
\hline & $\begin{array}{l}\text { Unstd. } \\
\text { Coeff. }\end{array}$ & t-stat & $\begin{array}{l}\text { Std. } \\
\text { Coeff. }\end{array}$ & $\begin{array}{c}\text { Contribution } \\
\text { to Variance } \\
(\%)\end{array}$ & $\begin{array}{l}\text { Unstd. } \\
\text { Coeff. }\end{array}$ & t-stat & Std. Coeff. & $\begin{array}{c}\text { Contribution } \\
\text { to Variance } \\
(\%)\end{array}$ \\
\hline No Health Problem & -0.086 & -46.644 & -0.082 & 5.467 & -0.052 & -31.021 & -0.057 & 4.926 \\
\hline Belief in Hard Work & -0.041 & -19.797 & -0.036 & 1.740 & -0.035 & -18.532 & -0.036 & 3.412 \\
\hline Freedom & -0.050 & -28.362 & -0.050 & 2.960 & -0.041 & -25.199 & -0.047 & 5.803 \\
\hline Some College/College & & & & & & & & \\
\hline Diploma & 0.013 & 5.451 & 0.010 & 0.175 & -0.012 & -5.767 & -0.010 & 0.237 \\
\hline Log Household Income & -0.011 & -14.458 & -0.035 & -0.851 & -0.008 & -11.467 & -0.028 & 1.158 \\
\hline Full-Time Employee & 0.066 & 30.463 & 0.064 & 2.758 & 0.015 & 7.859 & 0.017 & -0.005 \\
\hline Self-Employed & 0.057 & 23.151 & 0.044 & -0.104 & 0.015 & 6.754 & 0.013 & -0.091 \\
\hline Voluntary Part-Time & 0.023 & 7.738 & 0.013 & -0.200 & 0.007 & 2.757 & 0.005 & -0.083 \\
\hline Unemployed & 0.067 & 20.235 & 0.037 & 1.018 & 0.044 & 14.414 & 0.028 & 1.346 \\
\hline Involuntary Part-Time & 0.052 & 17.116 & 0.031 & 0.117 & 0.031 & 11.022 & 0.021 & 0.338 \\
\hline Smiled Yesterday & -0.162 & -88.501 & -0.162 & 22.129 & -0.112 & -66.310 & -0.130 & 26.769 \\
\hline Learned Yesterday & -0.018 & -11.565 & -0.020 & 0.971 & -0.010 & -6.789 & -0.012 & 1.059 \\
\hline Demographic Variables & Yes & Yes & Yes & 4.809 & Yes & Yes & Yes & 6.422 \\
\hline Country and Year Dummies & Yes & Yes & Yes & 59.011 & Yes & Yes & Yes & 48.709 \\
\hline
\end{tabular}

Source: Gallup World Poll.

Notes: $N=339,993$. All regressions are for 2009-2011. Stress and Anger are binary variables coded as 1 if the respondent experienced this type of affect the day before and 0 otherwise. Household income is log-transformed and in international dollars (ID), which allows comparisons across countries and time. Total $\mathrm{R}^{2}$ represents the total amount of variance in the dependent variable explained by the independent variables. Relative importance values sum to 100 percent, representing the proportional contribution of each variable. 


\section{Endnotes}

${ }^{1}$ In this paper, we view the capacity to live a purposeful life as a cause of well-being, which allows us to study the relationship between its manifestations and subjective well-being. While Alkire, Finnis, and Nussbaum view agency as a part of human well-being (see Alkire, 2002; 2005), Sen (1985) and Crocker (2008) clearly distinguish between well-being and agency. Alkire (2005) introduces the idea that agency can be both a dimension and a cause of well-being.

${ }^{2}$ We use agency, autonomy, being in charge of one's own life, and capacity to lead a purposeful life interchangeably. This is in sharp distinction with the principal-agent terminology in institutional economics, according to which the agent acts on behalf of the principal (Crocker, 2012). We use the terms freedoms, opportunities, and capabilities interchangeably. For more nuanced definitions and distinctions and a philosophical discussion, see Sen (1985), Crocker (2008), and Crocker and Robeyns (2009).

${ }^{3}$ Unlike Sen and Crocker, Nussbaum (2011) offers a pre-determined list of ten central capabilities as the minimum threshold for human flourishing. Sen considers Nussbaum's list as one of many possible sets of capability lists and thinks that this list is too fixed and does not allow for evaluation and deliberation. According to Crocker (2008), moreover, there should be no list of capabilities as contexts vary and the lists cannot and should not be seen as a substitute for public dialogue and deliberation.

${ }^{4}$ Psychologists use the term "affect" to describe feelings and emotions (OECD, 2013).

${ }^{5}$ We use the term happiness to mean positive hedonic well-being. We use the terms affect and emotional states interchangeably. We use the terms life evaluation, life satisfaction, and evaluative well-being interchangeably.

${ }^{6}$ For a more detailed discussion of the application of subjective well-being metrics to policy questions, and in particular to questions of poverty and inequality, see Adler and Fleurbaey, eds. (forthcoming).

${ }^{7}$ The evidence on the validity and reliability of eudaimonic well-being metrics is less systematic (OECD, 2013). For recent efforts to develop and test survey-based eudaimonic metrics, see Waterman et al. (2010) and Schutte et al. (2013).

${ }^{8}$ See Alkire (2005) for a summary of subjective quantitative studies of human agency. Furthermore, Muffels and Headley (2013) offer a framework linking perceptions of human, social, and cultural capital and choices with subjective well-being, income, and employment security over time.

${ }^{9}$ Table A. 2 shows the main results excluding the smiling variable, and Table A.3 presents findings using an optimism control instead. The results in these tables should not be compared horizontally across world regions as the regressions have a different number of country dummies.

${ }^{10}$ This discussion draws on (Fields, 2004).

${ }^{11}$ We used the Stata package -ineqrbd- (Fiorio \& Jenkins, 2010) for the decompositions.

${ }^{12}$ For further discussion of the quantile regression method, see Buchinsky (1998), Cade and Noon (2003), and Koenker and Hallock (2001).

${ }^{13}$ For details on the number of observations and per capita income per country, see Appendix Table 4. 
${ }^{14}$ Individuals respond differently to subjective well-being questions in face-to-face vs. on the telephone interviews. Dolan and Kavetsos (2012) find that in-person happiness responses are biased downwards compared to telephone responses in the UK. While we cannot control for this as precisely as we would like, our regressions have country dummies, which should, at least in part, capture differences in response modes across countries. Panel data from the UK show that a partner's presence during the interview was associated with under-reporting job satisfaction, while the presence of children increased the likelihood of over-reporting it for women (Conti \& Pudney 2011). We do not have a variable for whether the partner or children were present at the time of the interview in GWP but could control for audience effects by including controls for household size, marital status, and presence of children in the household.

${ }^{15}$ The question was not asked in every country. Those included are: Albania, Bangladesh, Bosnia and Herzegovina, Bulgaria, Chad, Croatia, Indonesia, Kazakhstan, Kosovo, Kyrgyzstan, Macedonia, Malaysia, Mali, Montenegro, Niger, Nigeria, Senegal, Serbia, Tajikistan, Tanzania, and Turkey.

${ }^{16} \mathrm{We}$ considered an indicator for whether the respondent has the opportunity to do her best at work and an indicator for whether she could choose how to spend her time. However, we excluded these as most observations were missing.

${ }^{17}$ The absence of a health problem variable is insignificant in Anand et al.'s SWB regression (2011).

${ }^{18}$ Anand et al. (2011) use a generalized linear latent and mixed model (GLAMM) to assess the impact of capabilities on life satisfaction in the presence of endogeneity (i.e., personality traits) and find that the GLAMM results do not differ from their baseline findings (i.e., those not correcting for endogeneity). They conclude that even though some personality traits may be relevant for the capability-happiness relationship, their inclusion or exclusion makes little difference for the overall direction and magnitude of the results. However, their dependent variable is satisfaction with life overall (and not best possible life), which does not allow them to discern the role of unobservable personality traits for the two different wellbeing dimensions that we include in our analysis.

${ }^{19}$ The EU-15 countries are: Austria, Belgium, Denmark, Finland, France, Germany, Greece, Ireland, Italy, Luxembourg, Netherlands, Portugal, Spain, Sweden, and United Kingdom. The transition economies are: Albania, Armenia, Azerbaijan, Belarus, Bosnia and Herzegovina, Bulgaria, Croatia, Czech Republic, Estonia, Georgia, Hungary, Kazakhstan, Kosovo, Kyrgyz Republic, Latvia, Lithuania, Macedonia FYR, Moldova, Mongolia, Montenegro, Poland, Romania, Russian Federation, Serbia, Slovak Republic, Slovenia, Tajikistan, Turkmenistan, Ukraine, and Uzbekistan. The twenty-five LAC countries are: Argentina, Belize, Bolivia, Brazil, Chile, Colombia, Costa Rica, Cuba, Dominican Republic, Ecuador, El Salvador, Guatemala, Guyana, Haiti, Honduras, Jamaica, Mexico, Nicaragua, Panama, Paraguay, Peru, Puerto Rico, Trinidad and Tobago, Uruguay, and Venezuela.

${ }^{20}$ As Tay and Diener (2011) advise, random measurement error might lower the total amount of the explained variance in the dependent variable if the underlying true well-being scores were perfectly measured. 
Table A.1. Dependent Variables and Focal Independent Variables

\begin{tabular}{|c|c|}
\hline Concept & Measure \\
\hline \multicolumn{2}{|r|}{ Dependent Variables } \\
\hline Evaluative well-being & $\begin{array}{l}\text { Please imagine a ladder with steps numbered from } 0 \text { at the bottom to } 10 \text { at } \\
\text { the top. Suppose we say that the top of the ladder represents the best } \\
\text { possible life for you, and the bottom of the ladder represents the worst } \\
\text { possible life for you. On which step of the ladder would you say you } \\
\text { personally feel you stand at this time, assuming that the higher the step } \\
\text { the better you feel about your life, and the lower the step the worse you } \\
\text { feel about it? Which step comes closest to the way you feel? }\end{array}$ \\
\hline Positive hedonic well-being & $\begin{array}{l}\text { Did you experience the following feelings during a lot of the day } \\
\text { yesterday? How about happiness? }\end{array}$ \\
\hline Negative hedonic well-being & $\begin{array}{l}\text { Did you experience the following feelings during a lot of the day } \\
\text { yesterday? How about stress? }\end{array}$ \\
\hline Negative hedonic well-being & $\begin{array}{l}\text { Did you experience the following feelings during a lot of the day } \\
\text { yesterday? How about anger? }\end{array}$ \\
\hline Eudaimonic Well-Being & Do you feel your life has an important purpose or meaning? \\
\hline \multicolumn{2}{|r|}{ Proxies for Subjective Capabilities } \\
\hline Absence of a health problem & $\begin{array}{l}\text { Do you have any health problems that prevent you from doing any of the } \\
\text { things people your age normally can do? }\end{array}$ \\
\hline Belief in hard work & Can people in this country get ahead by working hard, or not? \\
\hline Freedom & $\begin{array}{l}\text { In this country, are you satisfied or dissatisfied with your freedom to } \\
\text { choose what you do with your life? }\end{array}$ \\
\hline \multicolumn{2}{|c|}{ Proxies for Objective Capabilities and Means } \\
\hline Income & Household Income (International Dollars) \\
\hline Education & $\begin{array}{l}\text { What is your highest completed level of education? } \\
\text { Response Categories: } \\
\text { * Completed elementary education or less (up to } 8 \text { years of basic } \\
\text { education) } \\
\text { * Secondary - Secondary education and some education beyond } \\
\text { secondary education ( } 9-15 \text { years of education) } \\
\text { * Completed four years of education beyond 'high school' and/or received } \\
\text { a 4-year college degree }\end{array}$ \\
\hline Employment status & $\begin{array}{l}\text { Response Categories: } \\
\text { * Employed full time for an employer } \\
\text { * Employed full time for self } \\
\text { * Employed part time do not want full time } \\
\text { * Unemployed } \\
\text { * Employed part time want full time } \\
\text { * Out of workforce }\end{array}$ \\
\hline
\end{tabular}

Source: https://wpr.gallup.com/default.aspx 
Table A.2. Relative Importance of Capabilities and Means, by World Regions, without a Control for Smiling

\begin{tabular}{lcccc|cccc}
\hline & \multicolumn{4}{c}{ BPL } & \multicolumn{4}{c}{ Happiness Yesterday } \\
\cline { 2 - 9 } & World & Transition & EU-15 & LAC & World & Transition & EU-15 & LAC \\
\hline No Health Problem & 3.551 & 9.677 & 10.363 & 8.093 & 6.507 & 7.746 & 4.417 & 11.490 \\
Belief in Hard Work & 1.698 & 6.990 & 5.599 & 1.025 & 5.382 & 5.231 & 4.825 & 5.152 \\
Freedom & 3.7448 & 7.474 & 10.146 & 2.493 & 7.893 & 7.126 & 6.153 & 11.183 \\
Some College/College Diploma & 3.5362 & 3.645 & 3.349 & 3.523 & 0.100 & 0.240 & -0.726 & 0.357 \\
Log Household Income & 27.8391 & 26.827 & 16.072 & 13.066 & 5.369 & 4.466 & 3.666 & 3.581 \\
Full-Time Employee & 0.4799 & 0.245 & 0.481 & 1.164 & -0.194 & -0.319 & -0.340 & -0.129 \\
Self-Employed & 0.1751 & 0.056 & 0.038 & 0.523 & -0.017 & 0.041 & 0.029 & -0.003 \\
Voluntary Part-Time & 0.0453 & 0.230 & 0.911 & 0.030 & 0.012 & 0.110 & 0.342 & 0.009 \\
Unemployed & 0.9235 & 1.787 & 4.117 & 2.431 & 0.557 & 0.599 & 1.058 & 0.875 \\
Involuntary Part-Time & 0.3797 & 0.134 & 0.362 & 0.922 & 0.014 & -0.030 & -0.026 & 0.056 \\
Learned Yesterday & 5.5285 & 9.768 & 8.554 & 6.486 & 29.413 & 34.227 & 24.480 & 41.357 \\
Demographic Variables & 2.6071 & 10.707 & 3.889 & 12.490 & 5.080 & 20.312 & 7.436 & 10.132 \\
Country and Year Dummies & 49.4921 & 22.463 & 36.121 & 47.753 & 39.885 & 20.250 & 48.686 & 15.940 \\
$\mathrm{R}^{2}$ & 0.297 & 0.247 & 0.258 & 0.158 & 0.158 & 0.177 & 0.155 & 0.078 \\
\hline
\end{tabular}

Source: Gallup World Poll.

Notes: Notes: All regressions are for 2009-2012. Best Possible Life measures the respondent's assessment of her current life relative to her best possible life on a scale of 0 to 10 , where 0 is the worst possible life, and 10 is the best possible life. Happiness yesterday is coded as 1 if the respondent experienced this type of affect the previous day and 0 otherwise. Household income is log-transformed and is in international dollars (ID), which allows comparisons across countries and time. Total $\mathrm{R}^{2}$ represents the total amount of variance in the dependent variable explained by the independent variables. Relative importance values sum to 100 percent, representing the proportional contribution of each variable. LAC $=\mathrm{Latin}$ America and the Caribbean. The number of observations is as follows: World: 342,385; Transition Economies: 61,436; EU-15: 33,117; LAC: 49, 849. 
Table A.3. Relative Importance of Capabilities and Means, by World Regions, Controlling for Optimism

\begin{tabular}{lcccc|cccc}
\hline & \multicolumn{4}{c|}{ BPL } & \multicolumn{4}{c}{ Happiness Yesterday } \\
\cline { 2 - 8 } & World & Transition & EU-15 & LAC & World & Transition & EU-15 & LAC \\
\hline No Health Problem & 2.745 & 7.719 & 7.636 & 5.851 & 5.167 & 3.665 & 2.938 & 10.094 \\
Belief in Hard Work & 0.960 & 5.631 & 5.189 & 0.453 & 4.155 & 5.685 & 3.917 & 2.644 \\
Freedom & 2.546 & 4.399 & 6.069 & 2.171 & 7.307 & 5.575 & 3.319 & 10.008 \\
Some College/College & & & & & & & & \\
Diploma & 3.039 & 3.099 & 2.606 & 3.099 & 0.004 & 0.005 & -0.741 & 0.257 \\
Log Household Income & 32.297 & 39.508 & 22.919 & 14.734 & 6.129 & 3.473 & 6.928 & 4.478 \\
Full-Time Employee & 0.389 & -0.245 & 1.070 & 1.265 & -0.206 & -0.143 & -0.130 & 0.124 \\
Self-Employed & 0.333 & 0.019 & -0.012 & 0.460 & -0.016 & 0.310 & 0.052 & -0.007 \\
Voluntary Part-Time & 0.022 & 0.364 & 0.760 & 0.006 & 0.022 & 0.364 & 1.265 & 0.025 \\
Unemployed & 1.190 & 1.411 & 2.811 & 3.675 & 0.544 & 0.514 & 1.165 & 1.515 \\
Involuntary Part-Time & 0.360 & 0.166 & 0.034 & 0.642 & 0.050 & 0.011 & 0.139 & 0.018 \\
Optimism Control & 0.948 & 5.129 & 5.712 & 2.500 & 4.716 & 11.574 & 14.250 & 15.222 \\
Learned Yesterday & 5.291 & 7.814 & 7.127 & 6.591 & 26.853 & 28.847 & 21.220 & 35.414 \\
Demographic Variables & 2.512 & 7.271 & 2.211 & 9.231 & 3.768 & 20.909 & 8.722 & 9.204 \\
Country and Year Dummies & 47.367 & 17.715 & 35.868 & 49.320 & 41.506 & 19.212 & 36.957 & 11.004 \\
$R^{2}$ & 0.305 & 0.262 & 0.292 & 0.171 & 0.174 & 0.213 & 0.185 & 0.089 \\
\hline
\end{tabular}

Source: Gallup World Poll.

Notes: Notes: All regressions are for 2009-2012. Best Possible Life measures the respondent's assessment of her current life relative to her best possible life on a scale of 0 to 10 , where 0 is the worst possible life, and 10 is the best possible life. Happiness yesterday is coded as 1 if the respondent experienced this type of affect the previous day and 0 otherwise. Household income is log-transformed and is in international dollars (ID), which allows comparisons across countries and time. Total $\mathrm{R}^{2}$ represents the total amount of variance in the dependent variable explained by the independent variables. Relative importance values sum to 100 percent, representing the proportional contribution of each variable. LAC $=$ Latin America and the Caribbean. The number of observations is as follows: World: 121,432; Transition Economies: 14,964; EU-15: 7,462; LAC: 22,387. 
Table A.4: GWP Clean Data 2009-2012, Number of Observations by Country

\begin{tabular}{|c|c|}
\hline Country & Observations \\
\hline Afghanistan & 2,409 \\
\hline Albania & 1,948 \\
\hline Algeria & 2,866 \\
\hline Angola & 671 \\
\hline Argentina & 2,884 \\
\hline Armenia & 2,521 \\
\hline Australia & 2,420 \\
\hline Austria & 2,406 \\
\hline Azerbaijan & 1,088 \\
\hline Bahrain & 659 \\
\hline Bangladesh & 3,330 \\
\hline Belarus & 1,867 \\
\hline Belgium & 981 \\
\hline Benin & 1,598 \\
\hline Bolivia & 2,401 \\
\hline Bosnia and Herzegovina & 2,135 \\
\hline Botswana & 2,661 \\
\hline Brazil & 2,588 \\
\hline Bulgaria & 2,436 \\
\hline Burkina Faso & 2,714 \\
\hline Burundi & 1,701 \\
\hline Cambodia & 2,851 \\
\hline Cameroon & 2,961 \\
\hline Canada & 1,454 \\
\hline Central African & \\
\hline Republic & 1,805 \\
\hline Chad & 3,832 \\
\hline Chile & 3,122 \\
\hline China & 8,887 \\
\hline Colombia & 3,291 \\
\hline Comoros & 3,751 \\
\hline Congo (Kinshasa) & 2,225 \\
\hline Costa Rica & 2,262 \\
\hline Croatia & 1,660 \\
\hline Cyprus & 1,940 \\
\hline Czech Republic & 2,279 \\
\hline Denmark & 3,108 \\
\hline Djibouti & 612 \\
\hline Dominican Republic & 3,281 \\
\hline Ecuador & 1,717 \\
\hline Egypt & 3,761 \\
\hline
\end{tabular}


Table A.4 (cont'd)

El Salvador $\quad 2,795$

Estonia $\quad 1,220$

Ethiopia $\quad 1,410$

Finland 2,481

France $\quad 2,767$

Gabon $\quad 736$

Georgia 2,405

Germany 2,459

Ghana 2,654

Greece 2,876

Guatemala $\quad 1,485$

Guinea $\quad 1,662$

Haiti 793

Honduras $\quad 3,178$

Hong Kong 2,384

Hungary $\quad 2,188$

Iceland 621

India $\quad 15,916$

Indonesia $\quad 3,395$

Iraq $\quad 1,582$

Ireland $\quad 2,319$

Israel 2,098

Italy $\quad 1,150$

Jamaica 225

Japan $\quad 1,959$

Kazakhstan $\quad 1,678$

Kenya $\quad 1,829$

Kosovo $\quad 1,966$

Kuwait $\quad 570$

Kyrgyzstan 2,877

Laos 939

Latvia $\quad 1,481$

Lebanon 2,010

Lesotho 531

Liberia 891

Lithuania 2,009

Luxembourg $\quad 1,965$

Macedonia $\quad 1,769$

Madagascar $\quad 1,886$

Malawi 2,753 
Table A.4 (Cont'd)

\begin{tabular}{|c|c|}
\hline Malaysia & 3,070 \\
\hline Mali & 3,608 \\
\hline Malta & 1,343 \\
\hline Mauritania & 3,485 \\
\hline Mauritius & 919 \\
\hline Mexico & 2,016 \\
\hline Moldova & 2,126 \\
\hline Mongolia & 2,123 \\
\hline Montenegro & 1,824 \\
\hline Morocco & 863 \\
\hline Mozambique & 979 \\
\hline Myanmar & 896 \\
\hline Nepal & 2,267 \\
\hline Netherlands & 1,797 \\
\hline New Zealand & 2,190 \\
\hline Nicaragua & 2,424 \\
\hline Niger & 3,765 \\
\hline Nigeria & 2,703 \\
\hline North Cyprus & 367 \\
\hline Norway & 643 \\
\hline Pakistan & 2,105 \\
\hline Palestinian Territories & 2,595 \\
\hline Panama & 3,155 \\
\hline Paraguay & 3,355 \\
\hline Peru & 2,993 \\
\hline Philippines & 4,519 \\
\hline Poland & 2,115 \\
\hline Portugal & 1,657 \\
\hline Qatar & 772 \\
\hline Romania & 1,958 \\
\hline Russia & 5,024 \\
\hline Rwanda & 2,516 \\
\hline Senegal & 3,683 \\
\hline Serbia & 2,061 \\
\hline Sierra Leone & 1,904 \\
\hline Singapore & 2,117 \\
\hline Slovakia & 1,599 \\
\hline Slovenia & 2,695 \\
\hline Somaliland region & 3,868 \\
\hline South Africa & 3,737 \\
\hline South Korea & 1,933 \\
\hline Spain & 2,842 \\
\hline
\end{tabular}


Table A.4 (Cont'd)

Sri Lanka

3,323

Sudan

3,549

Suriname

Swaziland

637

Sweden

2,910

Switzerland $\quad 1,247$

Syria

1,100

Taiwan

2,105

Tajikistan

2,466

Tanzania

3,659

Thailand

4,417

Togo

694

Trinidad \& Tobago 222

Tunisia

1,659

Turkey

3,678

Turkmenistan

516

Uganda

2,452

Ukraine

United Arab Emirates

705

United Kingdom

1,399

United States

1,414

Uruguay

2,683

Uzbekistan

1,335

Venezuela

2,037

Vietnam

1,925

Yemen

2,350

Zambia

1,765

Zimbabwe

1,766

Source: Gallup World Poll.

Notes: The table details the final number of observation for each country included in the analysis after cleaning the dataset and removing missing observations, "Do not know," and "Refused" responses for all variables used in the analyses. Only countries which have data on all variables used in the analyses are included. 